\title{
The G4Foam Experiment: global climate impacts of regional ocean albedo modification
}

\author{
Corey J. Gabriel ${ }^{1}$, Alan Robock ${ }^{1}$, Lili Xia ${ }^{1}$, Brian Zambri ${ }^{1}$, and Ben Kravitz ${ }^{2}$ \\ ${ }^{1}$ Department of Environmental Sciences, Rutgers University, New Brunswick, NJ, USA \\ ${ }^{2}$ Atmospheric Sciences and Global Change Division, Pacific Northwest National Laboratory, Richland, Washington, USA \\ Correspondence to: Corey J. Gabriel (cjgabriel7@gmail.com)
}

Received: 29 September 2016 - Published in Atmos. Chem. Phys. Discuss.: 5 October 2016

Revised: 1 December 2016 - Accepted: 22 December 2016 - Published: 12 January 2017

\begin{abstract}
Reducing insolation has been proposed as a geoengineering response to global warming. Here we present the results of climate model simulations of a unique Geoengineering Model Intercomparison Project Testbed experiment to investigate the benefits and risks of a scheme that would brighten certain oceanic regions. The National Center for Atmospheric Research CESM CAM4-Chem global climate model was modified to simulate a scheme in which the albedo of the ocean surface is increased over the subtropical ocean gyres in the Southern Hemisphere. In theory, this could be accomplished using a stable, nondispersive foam, comprised of tiny, highly reflective microbubbles. Such a foam has been developed under idealized conditions, although deployment at a large scale is presently infeasible. We conducted three ensemble members of a simulation (G4Foam) from 2020 through to 2069 in which the albedo of the ocean surface is set to 0.15 (an increase of $150 \%$ ) over the three subtropical ocean gyres in the Southern Hemisphere, against a background of the RCP6.0 (representative concentration pathway resulting in $+6 \mathrm{~W} \mathrm{~m}^{-2}$ radiative forcing by 2100) scenario. After 2069, geoengineering is ceased, and the simulation is run for an additional 20 years. Global mean surface temperature in G4Foam is $0.6 \mathrm{~K}$ lower than RCP6.0, with statistically significant cooling relative to RCP6.0 south of $30^{\circ} \mathrm{N}$. There is an increase in rainfall over land, most pronouncedly in the tropics during the June-July-August season, relative to both G4SSA (specified stratospheric aerosols) and RCP6.0. Heavily populated and highly cultivated regions throughout the tropics, including the Sahel, southern Asia, the Maritime Continent, Central America, and much of the Amazon experience a statistically significant increase in precipitation minus evaporation. The temperature response to
\end{abstract}

the relatively modest global average forcing of $-1.5 \mathrm{~W} \mathrm{~m}^{-2}$ is amplified through a series of positive cloud feedbacks, in which more shortwave radiation is reflected. The precipitation response is primarily the result of the intensification of the southern Hadley cell, as its mean position migrates northward and away from the Equator in response to the asymmetric cooling.

\section{Introduction}

\subsection{Background}

The current rate of increase in global mean surface temperature is unprecedented in the last 1000 years (Marcott et al., 2013). The atmospheric concentration of $\mathrm{CO}_{2}$ is higher now than at any time in the last 650000 years (Siegenthaler et al., 2005). It is extremely likely that the warming since 1950 is primarily the result of anthropogenic emission of heat-trapping gases rather than natural climate variability (IPCC, 2013). Motivated by insufficient progress in setting and achieving mitigation targets, solar radiation management (SRM) has been proposed as a method of reducing global mean temperature, thereby ameliorating many of the negative effects of global warming (Crutzen, 2006). The most discussed SRM approach involves injection of sulfur dioxide $\left(\mathrm{SO}_{2}\right)$ into the tropical stratosphere. Other suggested SRM geoengineering methods include marine cloud brightening (Jones et al., 2009; Rasch et al., 2009; Latham et al., 2012) and surface albedo modification (Irvine et al., 2011; Cvijanovic et al., 2015; Mengis et al., 2016). Each of these methods has the potential to cool Earth's surface, but 


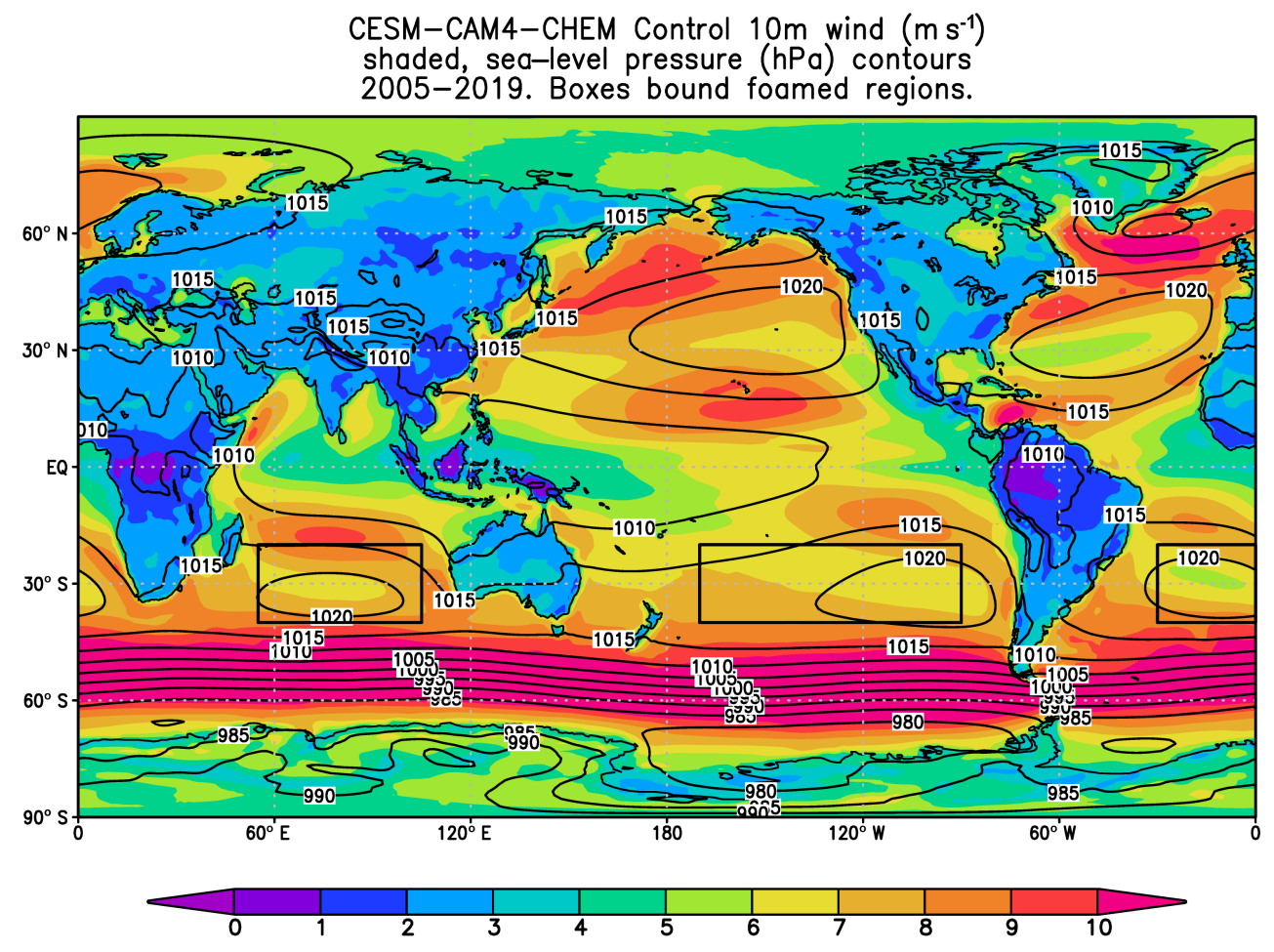

Figure 1. Applied forcing and global mean temperature response. Ocean albedo changed from a daily average of 0.06 , which includes a very small daily cycle, to a fixed value of 0.15 with no daily cycle, over "foam regions", $20^{\circ} \mathrm{N}-20^{\circ} \mathrm{S}, 90-170^{\circ} \mathrm{W}$ (South Pacific Ocean), $20^{\circ} \mathrm{N}-20^{\circ} \mathrm{S}, 30^{\circ} \mathrm{W}-0^{\circ} \mathrm{E}$ (South Atlantic Ocean) and $20^{\circ} \mathrm{N}-20^{\circ} \mathrm{S}, 55-105^{\circ} \mathrm{E}$ (South Indian Ocean). Each foamed region is outlined in black. Control-run sea-level pressure $(\mathrm{mb})$ is shown with contours and $10 \mathrm{~m}$ winds $\left(\mathrm{m} \mathrm{s}^{-1}\right)$ are shaded.

each comes with known potential side effects. For example, Robock $(2008,2014,2016)$ enumerated and described specific risks and benefits of stratospheric geoengineering.

Here we present a Geoengineering Model intercomparison Project (GeoMIP) Testbed experiment (Kravitz et al., 2011, 2015), consisting of the novel implementation of an ocean surface albedo modification scheme in a climate model, which simulates the placement of a reflective foam, consisting of microbubbles, on the ocean surface. RCP6.0 and G4SSA are run with an ocean surface albedo with a very small diurnal cycle, and the daily average albedo is very close to 0.06 . In our experiment, the albedo of the ocean surface is raised from this daily mean of 0.06 to a constant value of 0.15 , with no daily cycle, over the subtropical ocean gyres in the Southern Hemisphere, specifically $20^{\circ} \mathrm{N}-20^{\circ} \mathrm{S}$, $90-170^{\circ} \mathrm{W}$ (South Pacific Ocean), $20^{\circ} \mathrm{N}-20^{\circ} \mathrm{S}, 30^{\circ} \mathrm{W}-0^{\circ} \mathrm{E}$ (South Atlantic Ocean) and $20^{\circ} \mathrm{N}-20^{\circ} \mathrm{S}, 55-105^{\circ} \mathrm{E}$ (South Indian Ocean; Fig. 1). Everywhere else, ocean surface albedo in G4Foam is calculated in the same way as in RCP6.0 and G4SSA. It is possible that the absence of a small daily cycle in albedo would result in a slightly different surface energy budget than would occur if the foamed regions exhibited variations in albedo. However, the foamed regions' albedos would likely fluctuate as a function of many things, including some movement of the foam itself, foam interaction with precipitation or aerosols, wind speed, and sun angle. Further study of the properties of the foam, including in ocean water with some turbulence, could provide information that would allow future modeling of the foam to include albedo fluctuations. This is the G4Foam experiment, which simulates a particular implementation of an idealized form of the technology described by Aziz et al. (2014), where stable reflective foam, suitable for use as SRM in ocean regions with limited nutrients that support little marine life, is made in the laboratory.

The broad idea of microbubble deployment as a form of SRM is explored by Seitz (2010). Here we only examine the potential benefits and risks of such a scheme, and do not advocate deployment of any form of geoengineering regardless of its present feasibility. Robock (2011) has cautioned against the potential implications of ocean albedo modification as presented by Seitz (2010).

Stratospheric sulfate injection (SSI) is the most discussed form of geoengineering and, given the current state of research, the most feasible (Dykema et al., 2014; Keith et al., 2014). Implementation of the G4Foam regional ocean albedo modification scheme could be considered with or without concurrent SSI. G4Foam could be used as a potential SSI concurrent scheme aimed at correcting possible adverse impacts on the hydrological cycle brought about by ongoing SSI. G4Foam is also a potential alternative to SSI, with a far 
different latitudinal distribution of benefits. The focus here is solely on the second scenario, as it allows for the elucidation of the impacts of the G4Foam experiment forcing alone.

\subsection{Motivation and research question}

Is it possible to cool the planet while concurrently maintaining or increasing precipitation in highly populated and heavily cultivated regions, particularly in regions dependent on monsoon precipitation? We begin by determining whether a forcing can be applied in a global climate model (GCM) that will result in the model responding with a northward and landward shift of tropical precipitation needed to achieve our objective. To that end we conducted simulations with the Community Earth System Model 1 and Community Atmospheric Model 4 fully coupled to tropospheric and stratospheric chemistry (CESM1 CAM4-Chem) model (Lamarque et al., 2012; Tilmes et al., 2015, 2016). We ran the model with horizontal resolution of $0.9^{\circ} \times 1.25^{\circ}$ latitude-longitude and 26 levels from the surface to about $40 \mathrm{~km}(3.5 \mathrm{mb})$, as was done for G4SSA (specified stratospheric aerosol) by Xia et al. (2016).

The experiments consisted of three ensemble members of a simulation from 2020 to 2089 in which the ocean surface albedo is raised as described above from an average of 0.06 , which includes a small diurnal cycle of albedo, to a daytime constant 0.15 on the $\mathrm{SH}$ subtropical ocean gyres for 50 years, 2020-2069, and then returned to unforced values from 2070 to 2089 to assess termination. Our hypothesis is that the tropical rain belts will move northward largely as a result of increased moisture convergence over land regions, particularly during Northern Hemisphere (NH) summer (June-July-August, JJA) in NH monsoon regions. Enhanced divergence over the already strong subtropical highs, due to increased subsidence over the increased albedo ocean regions in the subtropical Southern Hemisphere ( $\mathrm{SH}$ ), would help the cooler air from the forced subtropical regions advect throughout the SH troposphere.

The asymmetric cooling would force changes in the Hadley cell, enhancing cross-equatorial flow, which would cool the surface in the NH tropics, especially during JJA, when heat mortality and morbidity is highest. However, despite a reduction in the JJA mean temperature in the tropics, extreme events are responsible for most heat-related mortality and morbidity, and the reduction in the mean temperature does not necessarily mean that there will be a reduction in the type of extreme heat events that cause human tragedy. While Kharin et al. (2007) showed that, in general, temperature extremes track with the mean temperature, this is not always the case. The changes in extreme events may, for example, be greater at high latitudes and the variability of temperatures over land may increase in a warmer climate.

Specific to geoengineering, Aswathy et al. (2015) showed that different climate engineering methods produce spatially heterogeneous changes in extreme precipitation and tempera- ture events. They showed that one SRM scheme may be more effective than another in reducing different types of extreme events despite relatively similar global and regional mean responses. In particular, a marine cloud brightening scheme that brightens ocean areas between $30^{\circ} \mathrm{N}$ and $30^{\circ} \mathrm{S}$ is shown to be less effective in reducing extreme precipitation and temperature events over land than the G3 experiment is.

Finally, the resulting cooling of low-latitude $\mathrm{NH}$ land areas would not dampen the monsoon. The wet-season monsoon circulation is initiated and maintained by the moist static energy gradient, not the surface temperature gradient. A wetter, more cloudy land mass will strengthen, not dampen, the circulation relative to a warmer, drier continent (Hurley and Boos, 2013), especially with a cooler, lower specific humidity environment under the descending branch of the meridional circulation.

The strength of this response will be very sensitive to any cloud feedbacks that result from the surface albedo forcing. The basis of this comprehensive hypothesis is described in detail, below, specifically in Sect. 1.3 and 1.4. The details of the experiment are discussed in detail in Sect. 2.

\subsection{Stratospheric geoengineering weakens the hydrological cycle}

With global warming, low-level specific humidity will increase by about $7 \% \mathrm{~K}^{-1}$ within the tropical planetary boundary layer. This response will be spatially homogeneous throughout the tropics. However, the precipitation response will be different. Increased moisture convergence in areas that already get a lot of precipitation will result in the "wet getting wetter," while increased moisture divergence in dry areas will result in the "dry getting drier" (Held and Soden, 2006).

The "rich get richer, poor get poorer" paradigm does not hold up in an SRM world, where the response is very different from that under global warming. Based on the results of an observational study, Trenberth and Dai (2007) pointed out the possibility that drought, particularly in the tropics, could result from geoengineering. Tilmes et al. (2013) analyzed the hydrological cycle in most of the GeoMIP participating Coupled Model Intercomparison Project 5 (CMIP5; Taylor et al., 2012) models by comparing abrupt 4xCO2, piControl, and G1. They found a robust reduction in global monsoon rainfall, including in the Asian and west African monsoon regions in $\mathrm{G} 1$ relative to both abrupt $4 \mathrm{xCO} 2$ and piControl. Haywood et al. (2013) explored the impact of SSI in one hemisphere only and found a movement of the Intertropical Convergence Zone (ITCZ) away from the hemisphere that was cooler as a result of the asymmetric SSI.

This consensus about the potential for less tropical rainfall under a regime of stratospheric SRM motivates us to identify an alternative or SSI-adjunctive geoengineering approach that could cool the planet, without reducing monsoon precipitation in highly cultivated areas. 


\subsection{Extratropical forcing impacts the position of the ITCZ}

Under global warming, tropical rain belts will move toward the hemisphere that warms more (Chiang and Bitz, 2005; Frierson and Hwang, 2012). This ITCZ migration was first seen in early atmosphere-ocean coupled models. Clouds were prescribed in those models, and when clouds were changed in such a way to preferentially cool one hemisphere, the ITCZ responded to changes by moving toward the warmer hemisphere. Increasing low-cloud cover, and thereby inducing cooling, in one hemisphere relative to the other caused the tropical rain belts over the Pacific Ocean to move toward the other hemisphere (Manabe and Stouffer, 1980). The impacts of asymmetric heating of the hemispheres became highly relevant during the Sahel drought. Much of the rainfall deficit during the devastating 20-30 year drought can be attributed to cooling initiated by increased tropospheric sulfate emissions in the NH (Hwang et al., 2013). The forced cooling over the $\mathrm{NH}$ was enhanced by a positive dynamical feedback in the North Atlantic Ocean (Broccoli et al., 2006; Kang et al., 2008), and the ITCZ and associated tropical rain belts migrated south. Since the Sahel is at the northern margin of the ITCZ's annual migration, or at the northern terminus of the west African monsoon, southward displacement of the ITCZ led to a devastating drought (Folland et al., 1986).

Broccoli et al. (2006) diagnosed the energy balance mechanism that causes the ITCZ to shift in response to asymmetric heating of the extratropics. Using models of varying complexity, Broccoli et al. (2006) imposed an anomalous cooling of the $\mathrm{NH}$, either via a last glacial maximum simulation, or via hosing of the North Atlantic. The heating asymmetry causes the extratropics in the $\mathrm{NH}$ to demand more heat and the extratropics in the SH to demand less heat. Since cross-equatorial heat transport is achieved principally via the Hadley cell, the SH Hadley cell strengthens, particularly in austral summer, in response to the NH cooling, and net energy flow in the upper branch intensifies, redistributing energy into the $\mathrm{NH}$ from the relatively warm $\mathrm{SH}$.

Net flow of energy in the Hadley cell can be described in terms of the flow of moist static energy, which flows in the direction of the upper-troposphere branch of the Hadley cell. This is because moist static energy is higher at higher altitudes in the troposphere due to the increased contribution of the geopotential energy term overwhelming the moisture and internal energy terms in the moist static energy equation for the high-altitude air. Net transport of energy, occurring in the upper branch of the Hadley cell from the SH to the $\mathrm{NH}$, leads to increased moisture advection to the $\mathrm{SH}$ in the lower branch of the Hadley cell. This redistribution of energy causes the ascending branch of the Hadley cell to migrate to the warmer SH where moisture convergence is increased and convective quasi-equilibrium is achieved under the relatively narrow poleward-shifted ascending branch of the stronger SH winter Hadley cell. This mechanism leads to the southward-displaced tropical rain belts (Broccoli et al., 2006).

This result is consistent with Lindzen and Hou (1988), who used a relatively simple model to show that even a small movement of maximum heating poleward into one hemisphere causes great asymmetry in the Hadley cell, with the winter cell intensifying tremendously and the summer cell becoming rather modest. More recent work continues to elucidate the mechanism of extratropical forcing of the ITCZ (Kang et al., 2008). The ocean also plays a vital role in pushing the ITCZ into the warmer hemisphere (Xie and Philander, 1994).

GCM results confirm this mechanism and connect the changes due to northward displacement of the ITCZ with the onset of active periods in the Asian summer monsoon (Chao and Chen, 2001). It is evident that a geoengineering technique that could preferentially cool the SH could shift the tropical rain bands northward. However, in a GCM there are clouds. How would clouds respond in the hemisphere cooled by geoengineering? Would clouds change in the area being directly cooled? Would a cooling of the subtropics either directly, or indirectly via eddy flux from the artificially cool high latitudes, cause an increase in subtropical subsidence? Would this increase in the sinking of air above the intensified subtropical highs cause water vapor to be trapped in the lower troposphere, forming low clouds and suppressing water vapor mixing into the free troposphere, where the water vapor may instead be used up in formation of high clouds, which tend to reduce outgoing long-wave radiation? Informed by these established diagnostic mechanisms associated with the impacts of asymmetric heating of the hemispheres, we seek to concurrently cool the entire SH and the NH tropics, modestly cool the NH extratropics and, most importantly, induce an anomalous overturning circulation and redistribute rainfall from ocean to land and from south to north across the tropics.

\section{Methods}

\subsection{Design of experiment and model configuration}

Figure 1 shows the regions selected for albedo enhancement. These regions were chosen because of their low-cloud fraction, low wind speeds, weak currents, and lack of biological productivity.

We used the Community Land Model (CLM) version 4.0 with prescribed satellite phenology (CLM4SP) instead of the version of CLM with a carbon-nitrogen cycle, coupled with CAM4-chem. Vegetation photosynthesis is calculated under the assumption of prescribed phenology and no explicit nutrient limitations (Bonan et al., 2011; Xia et al., 2016). Dynamic vegetation is not turned on in this study. The ocean model does not include any biogeochemical responses. 
The fundamental question we wish to answer concerns representation of the physical processes that lead to realistic simulation tropical precipitation. The Asian monsoon is of great importance in that investigation. Fortunately, monsoon processes and regimes are depicted well in our atmospheric component, CAM4 (Meehl et al., 2012). Some important features of CAM4 that illustrate its good monsoon representation include the amount and location of precipitation over the southern Tibetan Plateau and over the Western Ghats (a mountain range near the west coast of south India). This is improved when compared to earlier versions of the model. The rain shadow leeward of this range is often not resolved by GCMs, however CAM4 shows some evidence of this rain shadow. These changes related to orography and horizontal resolution are important and likely generalize to similar land surface features outside of India, where model biases have not been as carefully studied as they have been in heavily populated southern India. This improvement can be attributed to the CCSM4 finite-volume dynamical core, which replaces the spectral version of the CCSM3 and the interconnected higher horizontal resolution (Neale et al., 2013). Additionally, large-scale features are improved. For example, the representation of the ITCZ during NH winter southward migration over the Maritime Continent is improved (Meehl et al., 2012).

There is an important process associated with monsoon precipitation, however, that may be imperfectly simulated across many CMIP5 GCMs. Zonal mean absorbed shortwave radiation is too high over the Southern Ocean (Kay et al., 2016). This cloud problem leads to a warmer Southern Ocean, which leads to anomalous $\mathrm{SH}$ atmospheric eddy flux to the subtropics from the extratropics, potentially damping the cooling response of our negative surface radiative forcing in the subtropical oceans. The effect of a transfer of heat from the SH extratropics into the Hadley cell already causes a relatively weak negative bias in the amount of interhemispheric heat transport from the south to north. Therefore, the manifestation of this bias in G4Foam would be to partially offset our imposed cooling, lessening the need for interhemispheric energy transport to the $\mathrm{SH}$ and suppressing the surface return flow of moisture advection into the NH. Lower than observed interhemispheric energy transport would be associated with a weaker Asian monsoon. However, this feature is equally present in our G4Foam experiment and the comparison experiments G4SSA and RCP6.0, so is unlikely to appreciably affect the differences.

We compare G4Foam to two experiments. First is a specific sulfate injection scenario, G4 Specified Stratospheric Aerosol (G4SSA; Xia et al., 2016). They used a prescribed stratospheric aerosol distribution roughly analogous to annual tropical emission into the stratosphere (at $60 \mathrm{mb}$ ) of $8 \mathrm{Tg} \mathrm{SO}_{2} \mathrm{yr}^{-1}$ from 2020 to 2070 . This produces a radiative forcing of about $-2.5 \mathrm{~W} \mathrm{~m}^{-2}$. The G4SSA forcing ramps down from 2069 to 2071 and then continues without additional forcing from 2072 to 2089. In G4SSA tropospheric aerosols are not affected by the prescribed stratospheric aerosols. Therefore we cannot evaluate how stratospheric aerosols would actually fall out and impact the chemistry, dynamics and thermodynamics of the troposphere from this experiment. Neely et al. (2016) offers more detail on the prescription of stratospheric aerosols in CAM4-Chem. The second simulation for comparison, which serves as the reference simulation for both G4Foam and G4SSA, is the Representative Concentration Pathway 6.0 (RCP6.0) (Meinshausen et al., 2011) from 2004 to 2089. We have run three ensemble members each for G4Foam, G4SSA, and RCP6.0.

\subsection{Ocean albedo enhancement approach}

A plausible technology now exists to make quantities of long-lasting foam, or engineered microbubbles, to enhance ocean albedo. Ocean albedo modification gained attention when Seitz (2010) suggested that since air-water and airsea interfaces are similarly refractive, dispersing microbubbles onto the surface of the ocean would reflect sunlight in much the same way as cloud droplets do. While engineering refractive or stable foams is commonly done and applied in both food science and firefighting, engineering a stable and refractive foam appropriate for a geoengineering scheme appeared fanciful until Aziz et al. (2014) produced a long-lasting refractive foam made with biodegradable and non-toxic additives. Aziz et al. identified foam lifetime of 3 months or more per microbubble as lasting long enough that the input of energy to create the microbubbles would not be prohibitive. After experimenting with protein-only solutions, Aziz et al. (2014) added high methyl ester pectin to type A gelatin and created a foam in salt water, which was still intact and stable at the cessation of the experiment after 3 months. The reflectance of the foam was about $50 \%$, which is comparable to that of whitecaps. The creation of these stable microbubbles makes enhancing ocean albedo in this manner "feasible" (Aziz et al., 2014). However, there are a number of other potential risks associated with microbubble deployment, even if the feasibility issues are set aside. Robock (2011) pointed out that vertical mixing in the ocean, changes in ocean circulation, impacts on photosynthesis, and risks to the biosphere could all impair the efficacy of this geoengineering approach. Robock (2011) also pointed out that a cooler ocean would serve as a more effective $\mathrm{CO}_{2}$ sink, helping to offset the $\mathrm{CO}_{2}$ increase that comes about as a feedback of warming. Other potentially attractive attributes of this technique include the possibility that it could be deployed exclusively in the $20 \%$ of the world's oceans that are not biologically active (Aziz et al., 2014) and therefore have little impact on the biosphere, and that there would be no risk to ozone in the stratosphere. 


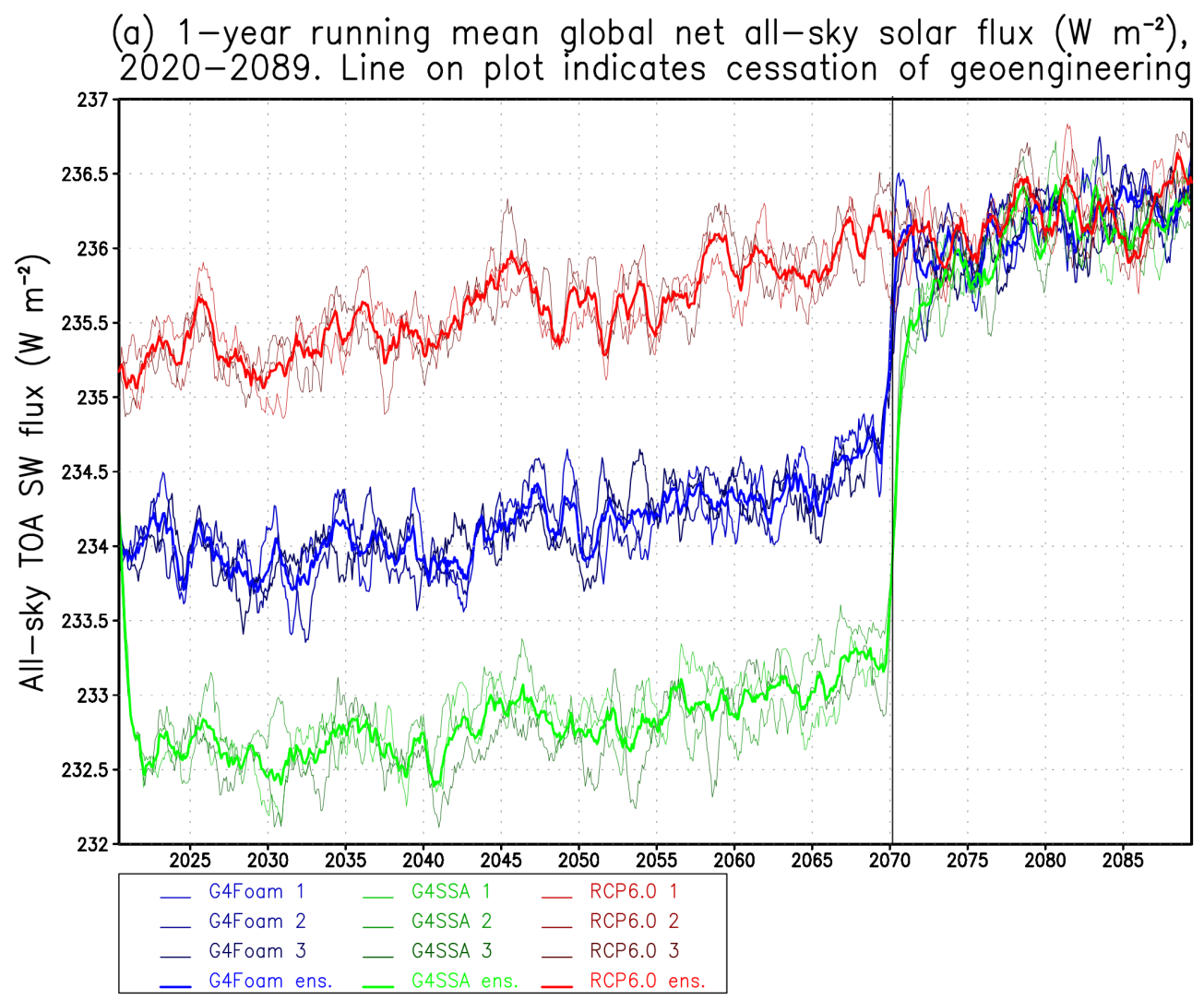

(b) 1-year running mean global net cloud forcing $\left(\mathrm{W} \mathrm{m}^{-2}\right)$,

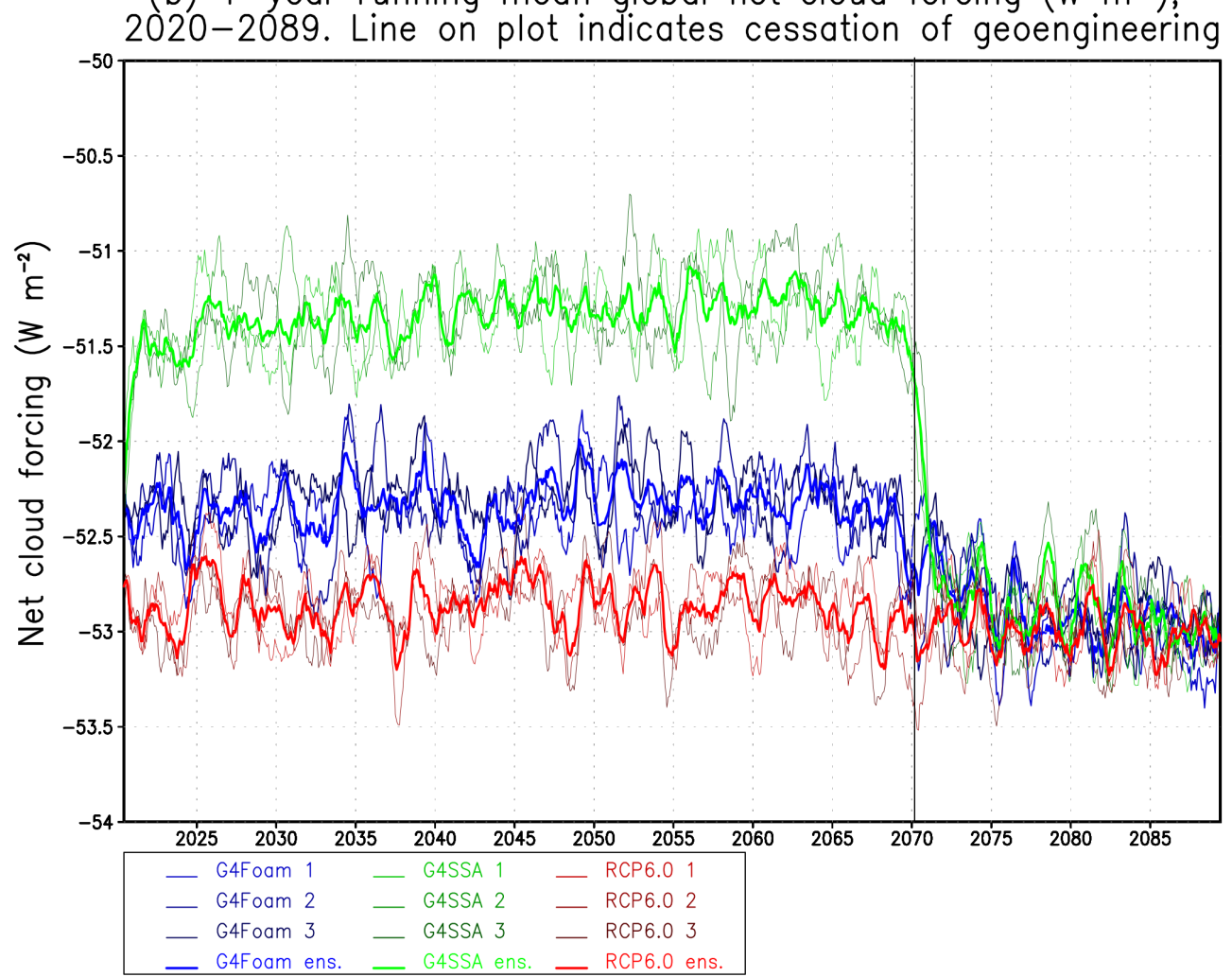

Figure 2. (a) Net all-sky SW flux at top of atmosphere and (b) time series of global mean net cloud forcing. Each ensemble member and the ensemble mean are shown for each forcing. 
(a) 1-year running mean global TOA net clear-sky SW flux $\left(\mathrm{W} \mathrm{m}^{-2}\right)$, 2020-2089. Line on plot indicates cessation of geoengineering

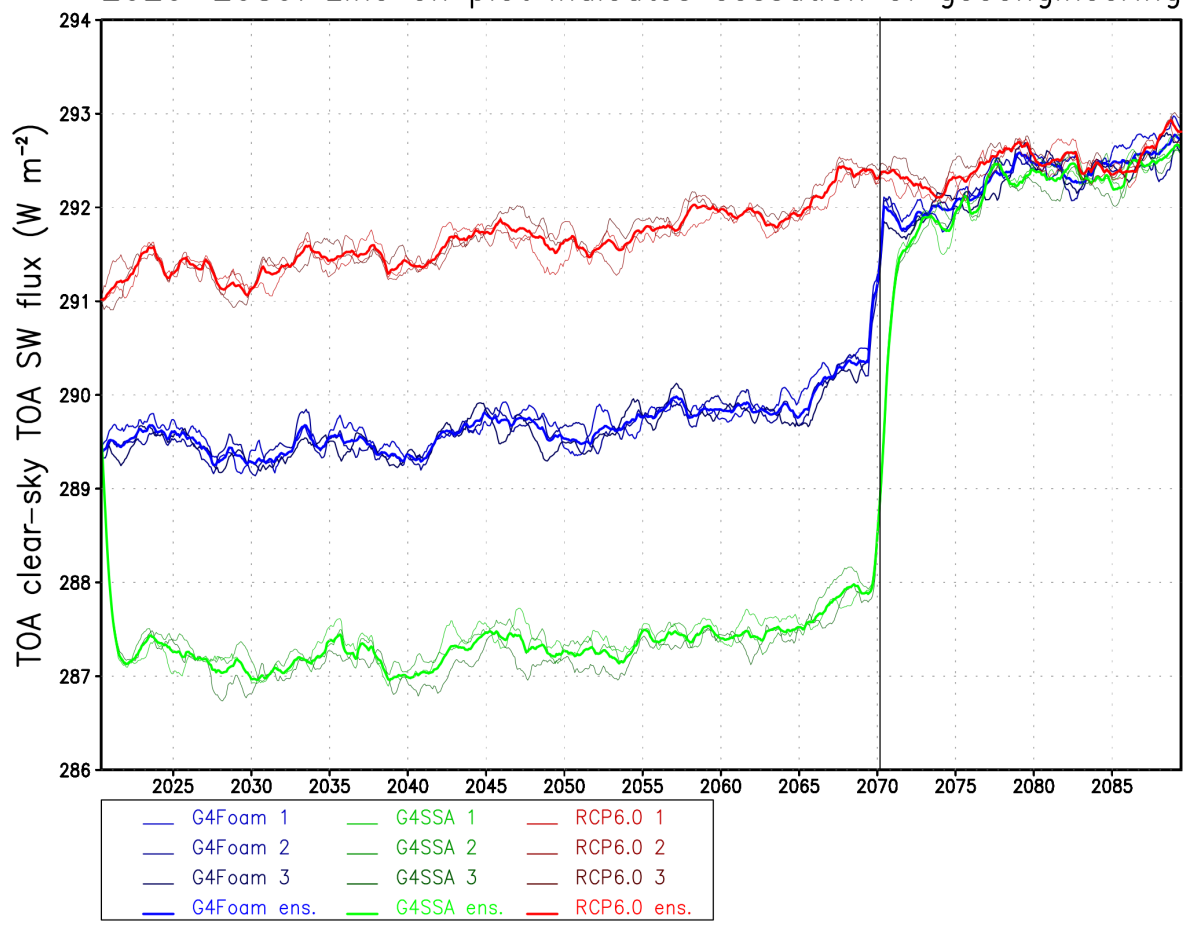

(b) 1-year running mean global surface temp. (K), 2020-2089. Line on plot indicates cessation of geoengineering

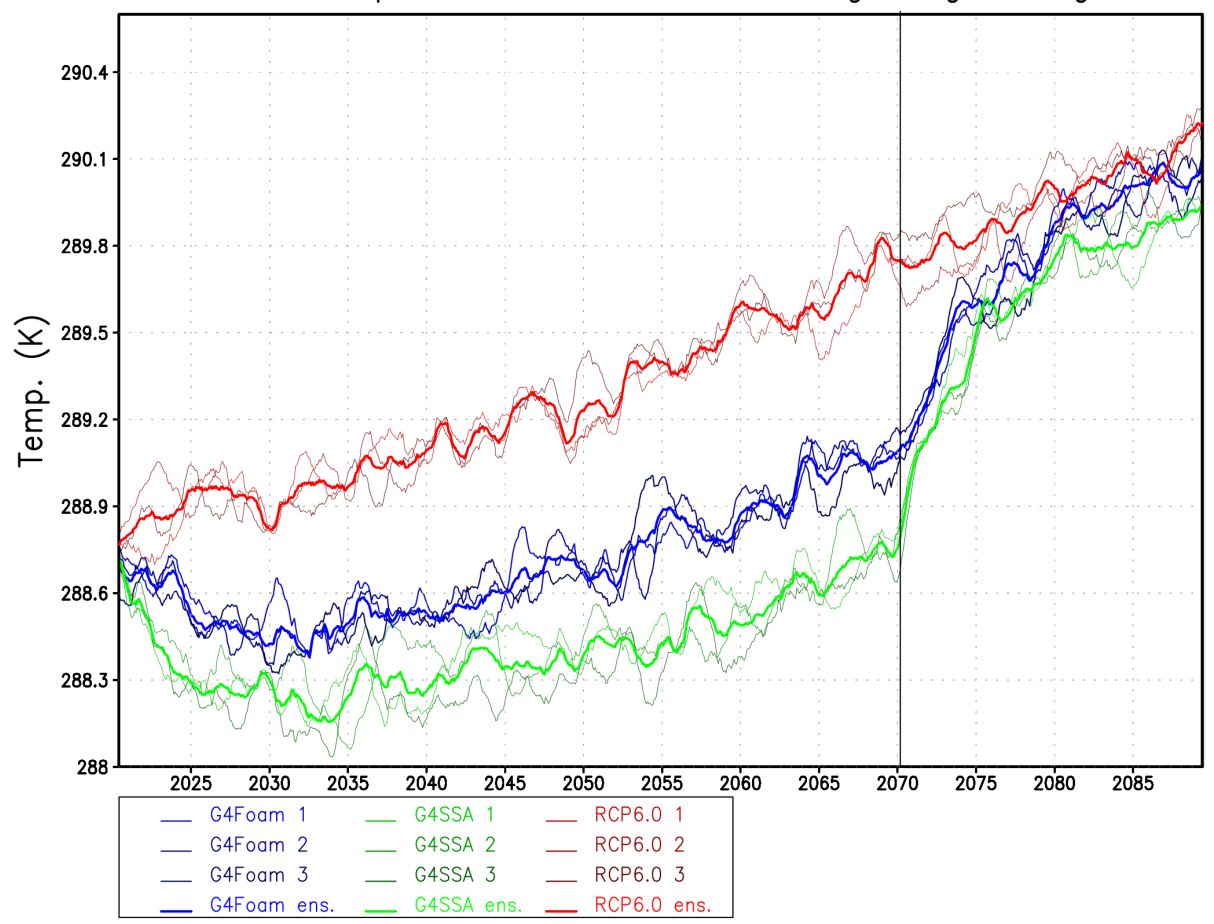

Figure 3. (a) Net clear-sky SW flux at top of atmosphere, which includes the effects of changes in radiation caused by changes in ocean surface albedo or land albedo (ice and snow), as well as stratospheric aerosols (stratospheric geoengineering) and (b) time series of global mean temperature. In G4Foam, temperature is more than twice as sensitive to ocean albedo forcing as it is to stratospheric geoengineering, as applied in G4SSA, albeit with very different latitudinal distributions of temperature changes. Each ensemble member and the ensemble mean are shown for each forcing. 
Table 1. Changes in temperature and precipitation in G4Foam relative to both G4SSA and RCP6.0, for the entire globe and for the Tropics $\left(20^{\circ} \mathrm{S}-20^{\circ} \mathrm{N}\right)$ annually and in Northern Hemisphere summer, for the 40-year period beginning 10 years after the start of climate engineering.

\begin{tabular}{|c|c|c|}
\hline Global, 2030-2069 & $\begin{array}{r}\text { G4Foam - G4SSA } \\
(\% \text { change })\end{array}$ & $\begin{array}{r}\text { G4Foam - RCP6. } 0 \\
(\% \text { change })\end{array}$ \\
\hline Precipitation $\left(\mathrm{mm} \mathrm{day}^{-1}\right)$ & $+0.02(+0.61)$ & $-0.06(-1.98)$ \\
\hline Land precipitation $\left(\mathrm{mm} \mathrm{day}^{-1}\right)$ & $+0.07(+3.19)$ & $+0.01(+0.32)$ \\
\hline Ocean precipitation $\left(\mathrm{mm} \mathrm{day}^{-1}\right)$ & $-0.01(-0.36)$ & $-0.08(-2.57)$ \\
\hline Temperature $(\mathrm{K})$ & +0.27 & -0.53 \\
\hline Land temperature $(\mathrm{K})$ & +0.63 & -0.44 \\
\hline \multicolumn{3}{|c|}{ Global, 2030-2069, June-July-August } \\
\hline Precipitation $\left(\mathrm{mm} \mathrm{day}^{-1}\right)$ & $+0.02(+0.70)$ & $-0.05(-1.85)$ \\
\hline Land precipitation (mm day ${ }^{-1}$ ) & $+0.08(+3.35)$ & $+0.02(+0.70)$ \\
\hline Ocean precipitation $\left(\mathrm{mm} \mathrm{day}^{-1}\right)$ & $+0.01(-0.29)$ & $-0.08(-2.51)$ \\
\hline Temperature $(\mathrm{K})$ & +0.32 & -0.60 \\
\hline Land temperature $(\mathrm{K})$ & +0.71 & -0.53 \\
\hline \multicolumn{3}{|c|}{ Tropical, 2030-2069 } \\
\hline Precipitation $\left(m m\right.$ day $\left.^{-1}\right)$ & $+0.06(+1.59)$ & $-0.03(-1.06)$ \\
\hline Land precipitation $\left(\mathrm{mm} \mathrm{day}^{-1}\right)$ & $+0.16(+3.93)$ & $+0.07(+1.43)$ \\
\hline Ocean precipitation $\left(\mathrm{mm} \mathrm{day}^{-1}\right)$ & $+0.03(+0.77)$ & $-0.07(-1.92)$ \\
\hline Temperature (K) & +0.21 & -0.60 \\
\hline Land temperature $(\mathrm{K})$ & +0.43 & -0.61 \\
\hline \multicolumn{3}{|c|}{ Tropical, 2030-2069, June-July-August } \\
\hline Precipitation $\left(\mathrm{mm} \mathrm{day}^{-1}\right)$ & $+0.06(+1.52)$ & $-0.03(-0.84)$ \\
\hline Land precipitation $\left(\mathrm{mm} \mathrm{day}^{-1}\right)$ & $+0.16(+4.66)$ & $+0.07(+2.02)$ \\
\hline Ocean precipitation $\left(\mathrm{mm} \mathrm{day}^{-1}\right)$ & $+0.03(+0.67)$ & $-0.06(-1.61)$ \\
\hline Temperature $(\mathrm{K})$ & +0.18 & -0.61 \\
\hline Land temperature $(\mathrm{K})$ & +0.37 & -0.70 \\
\hline
\end{tabular}

\section{Results}

The following results compare the G4Foam climate with the climates in G4SSA and RCP6.0 averaged over the period 2030-2069. While G4Foam and G4SSA forcing commences in 2020, the first ten years of both experiments are a period of transition. For that reason 2020-2029 is discarded from our comparisons. We analyze mainly annual average and JJA results, since JJA is meteorological summer in the NH and using JJA facilitates comparison with G4SSA, which reports results in terms of JJA (Xia et al., 2016).

\subsection{Temperature and cloud response}

The primary purpose of G4Foam is to assess the possibility of reducing global mean surface temperature without reducing monsoon precipitation. The G4Foam simulations reduce global mean surface temperature relative to RCP 6.0 by $0.60 \mathrm{~K}$ and global mean land surface temperature by $0.51 \mathrm{~K}$ relative to RCP6.0. In JJA, G4Foam is $0.70 \mathrm{~K}$ cooler than RCP6.0 over land in the tropics, $20^{\circ} \mathrm{S}-20^{\circ} \mathrm{N}$, during JJA (Table 1).
These temperature changes in G4Foam, relative to RCP6.0, result from an all-sky top-of-atmosphere forcing of $-1.5 \mathrm{~W} \mathrm{~m}^{-2}$ (global, year-round), and $-1.9 \mathrm{~W} \mathrm{~m}^{-2}$ in the tropics during JJA only (Fig. 2). This JJA cooling in the tropics is of particular importance due to the dense population and heavy agricultural demand in the tropics, particularly north of the equator.

G4Foam does not achieve the same amount of cooling as G4SSA, which would reduce global mean surface temperature by $0.92 \mathrm{~K}$. All-sky top-of-atmosphere shortwave flux in G4SSA is reduced by $2.7 \mathrm{~W} \mathrm{~m}^{-2}$ as compared to RCP6.0. In terms of global mean clear-sky top-of-atmosphere shortwave flux, relative to RCP6.0, G4Foam applies only $38 \%$ of the forcing that is applied in G4SSA (Fig. 3). The G4Foam forcing is more efficient in reducing temperature than G4SSA, largely because there is an additional $1.1 \mathrm{~W} \mathrm{~m}^{-2}$ of net cloud forcing in G4Foam relative to G4SSA (Fig. 2b).

Figure 4 shows a comparison of the spatial distribution of surface temperature changes between G4Foam and G4SSA and between G4Foam and RCP6.0 between 2030 and 2069. Over the SH ocean gyres that were brightened (Fig. 1), we see a very robust cooling, reaching $2 \mathrm{~K}$ at the center of the 
(a) Surface temp.: G4Foam-G4SSA (K)

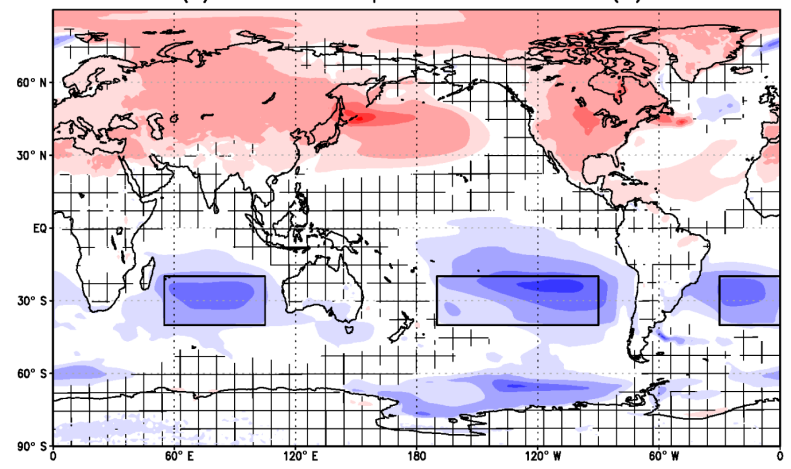

(c) JJA Surface temp.: G4Foam-G4SSA (K)

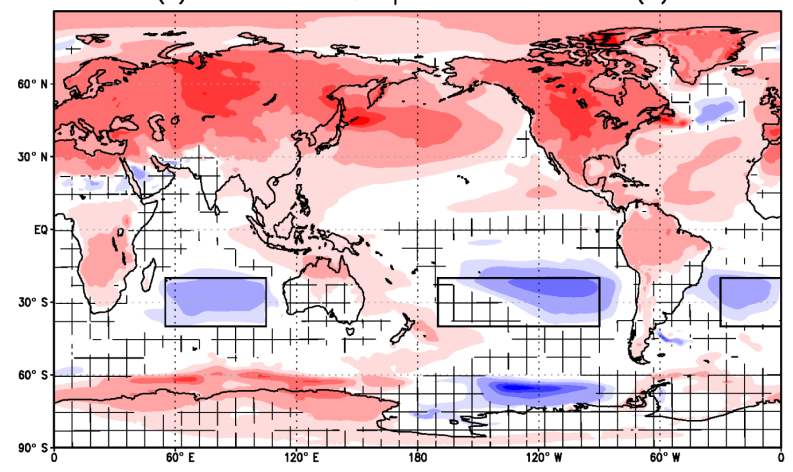

(b) Surface temp.: G4Foam-RCP6.0 (K)

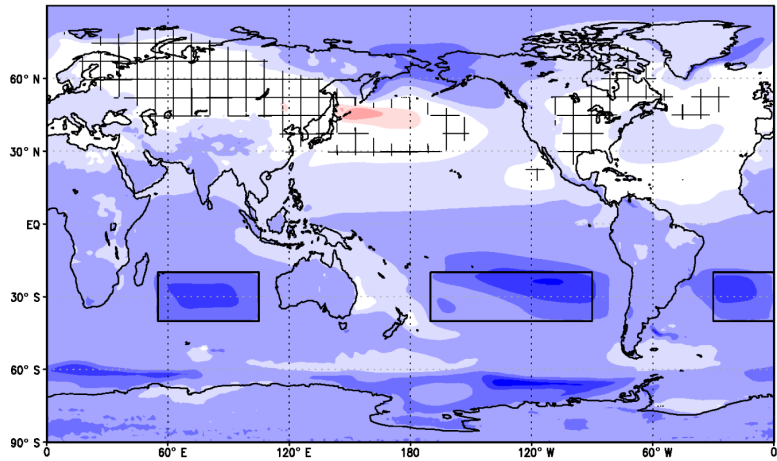

(d) JJA Surface temp.: G4Foam-RCP6.0 (K)

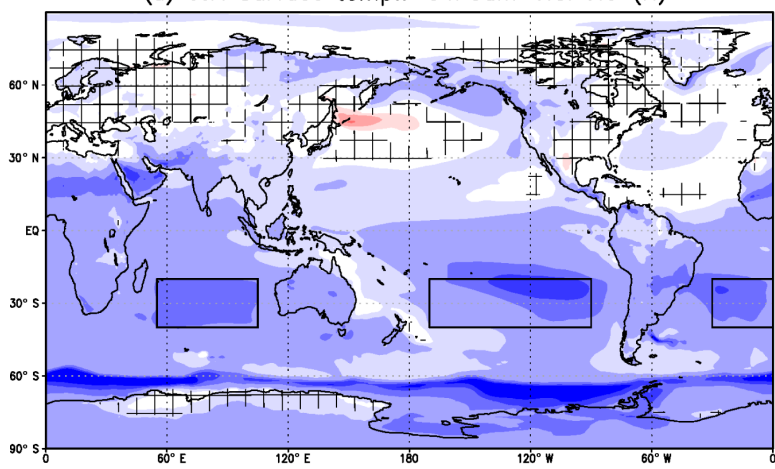

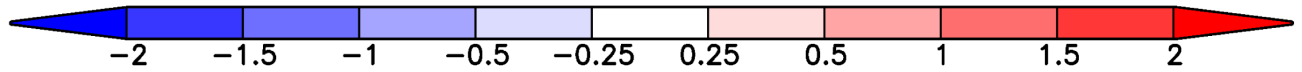

Figure 4. 2030-2069 surface temperature differences (K) between G4Foam and (a) G4SSA, (b) RCP6.0, (c) G4SSA during JJA, and (d) RCP6.0 during JJA. Hatched regions are areas with $p>0.05$ (where changes are not statistically significant based on a paired $t$ test). Black boxes enclose foamed regions.

South Pacific foamed region. However, the cooling mixes rather well throughout the SH. Cross-equatorial flow and changes in the Hadley cell transmit this cooling into the $\mathrm{NH}$ tropics through the mechanisms described in Sect. 1.4, above. Some of this cooling in the NH tropics is then transmitted to the NH extratropics.

G4Foam is significantly cooler $(p<0.05)$ than RCP6.0 in almost all locations south of $30^{\circ} \mathrm{N}$, in mid-latitude $\mathrm{NH}$ continental regions windward of the Atlantic and Pacific oceans, and at very high latitudes. Figure $4 \mathrm{~d}$ shows that G4Foam is less effective in cooling extratropical $\mathrm{NH}$ land regions during JJA. This is reasonable, since continental heating in the $\mathrm{NH}$ JJA season is more dominated by local heating than the other seasons, in which meridional energy transport plays a larger role. Figure $4 \mathrm{a}$ and $\mathrm{c}$ show that G4SSA is more effective over $\mathrm{NH}$ continents than G4Foam. A key weakness of G4Foam, if implemented alone, would be its failure to adequately reduce human suffering induced by heat stress in $\mathrm{NH}$ mid-latitudes during the summer as a result of ongoing global warming.

Since the G4Foam forcing alone, with the amplitude of the current experiments, would be insufficient to achieve any of the objectives of the G4Foam experiment, positive feedbacks that enhance cooling and circulation responses must be triggered by the G4Foam forcing to enhance a resulting cooler, wetter climate. Figure 5 shows change in low-cloud fraction both year-round and in the JJA season. The largest change is in the northern half of the regions where foam is applied, and the area to the north of those foamed regions. The changes in low clouds in these regions are both large and statistically significant.

The low-cloud fraction increase in the three areas to the north and northeast of the G4Foam-forced subtropical surface regions is likely due to a stronger than normal trade wind inversion (TWI). The inversion develops when warm air is trapped above the atmospheric mixed layer due to large-scale subsidence and surface mixing of cooler air above these relatively low SST regions. The increase in low-cloud fraction does not occur over the entire downwind area because SSTs increase from east to west, causing a change in the lower troposphere from east to west. Moving west, the stratocumulus layer, which is trapped under the inversion base, decouples from the mixed layer in the lower troposphere. The sur- 
(a) Low-cloud frac.: G4Foam-G4SSA

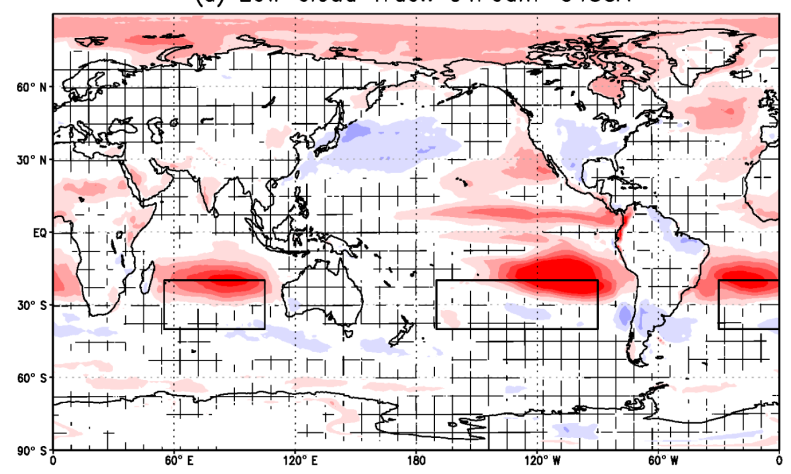

(c) JJA low-cloud frac:: G4Foam-G4SSA

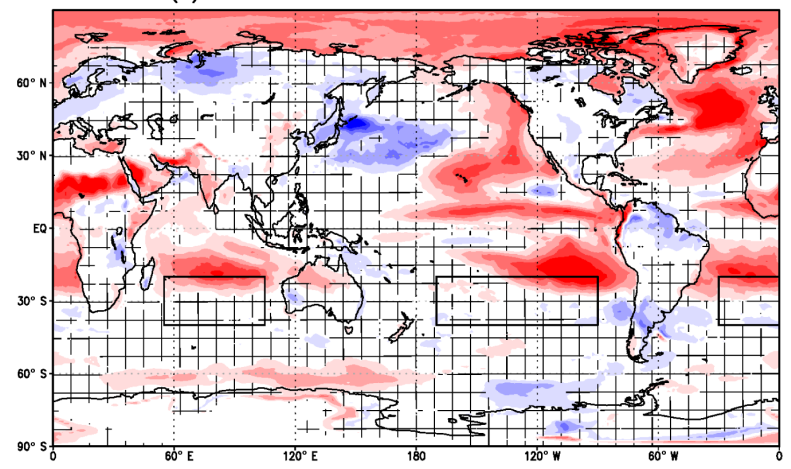

(b) Low-cloud frac.: G4Foam-RCP6.0

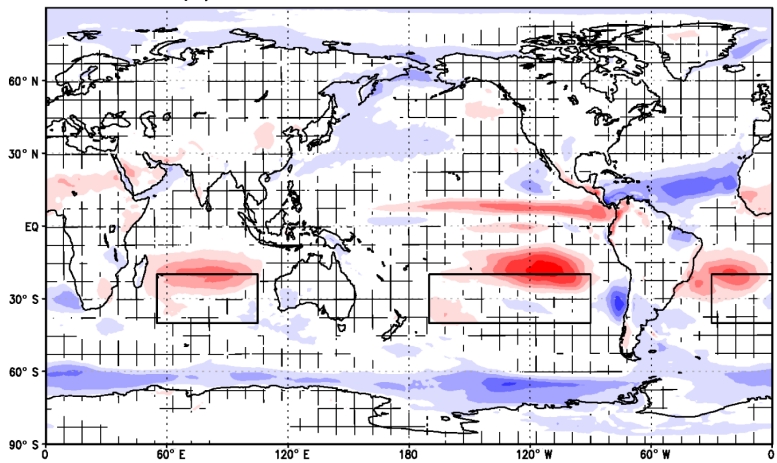

(d) JJA low-cloud frac.: G4Foam-RCP6.0

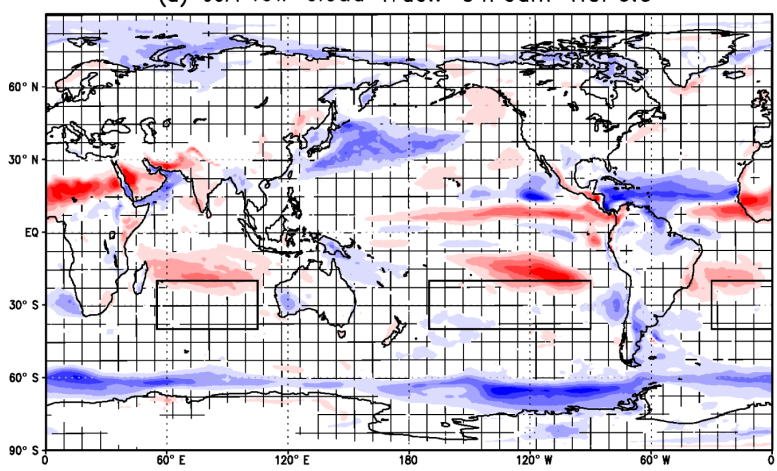

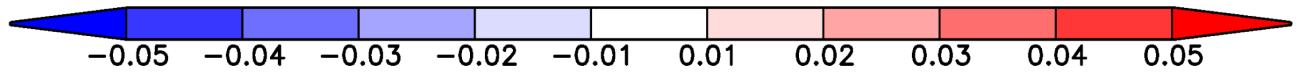

Figure 5. 2030-2069 low-cloud fraction difference (unitless) between G4Foam and (a) G4SSA, (b) RCP6.0, (c) G4SSA during JJA, and (d) RCP6.0 during JJA. Hatched regions are areas with $p>0.05$ (where changes are not statistically significant based on a paired $t$ test). Black boxes enclose foamed regions.

face warming triggers more turbulence within the planetary boundary layer, which allows for enhanced cumulus mixing in the cloud layer, which entrains dry air and evaporates the marine stratocumulus layer.

The subtropical high-pressure systems are stronger in G4Foam, due to the stronger than normal Hadley cell, which enhances subsidence throughout the subtropics. Typically, a subsidence inversion is strongest over the center of the subtropical anticyclones, over cold currents (particularly the Peru Current), and over cooler than normal waters, which are subjected to enhanced upwelling in large part by trade winds on the periphery of the subtropical highs (DeSzoeke et al., 2016). The TWI becomes weaker and its base increases in height as it moves towards the west and towards the equator, as SSTs increase. This pattern is particularly evident in the Pacific, due to the larger geographical extent of the forced area.

Specifically, under G4Foam conditions, the increased lowcloud fraction areas are the result of the combination of enhanced large-scale subsidence (stronger Hadley cell) and a cooler than normal ocean surface. The cooler than normal surface waters are due to general cooling throughout the $\mathrm{SH}$, as well as an increase in wind-driven upwelling over these areas of increased low-cloud fraction, which are already prone to upwelling, a large fraction of low clouds, and high relative humidity.

In these areas north of the foamed areas, the subsidence inversion is not quite as strong as it is right under the subtropical high. However, SSTs are artificially low, due to general cooling of the hemisphere and enhanced upwelling, driven by anomalously strong winds, and mixing of this anomalously cool surface air within the planetary boundary layer keeps the lowest levels of the atmosphere cool, keeping the marine air inversion base above the lifting condensation level and allowing stratocumulus clouds to form at low altitude, below the base of the inversion. Additionally, since SST is lower than air temperature in the areas of enhanced low clouds, the surface inversion is further maintained as a result of sensible heat flux from the atmosphere to the ocean. Ultimately, the strong inversion often results in more marine-layer cloud formation and longer times for the clouds to dissipate. This response is consistent through the 2030-2069 period. This 
(a) Total cloud frac.: G4Foam-G4SSA

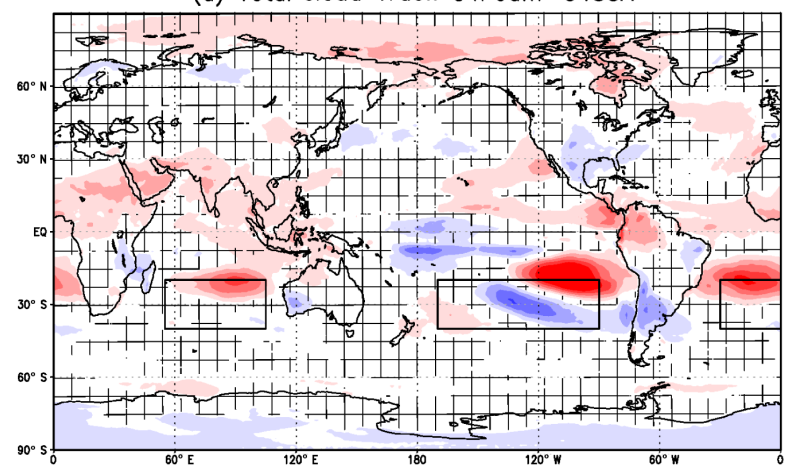

(c) JJA total cloud frac.: G4Foam-G4SSA

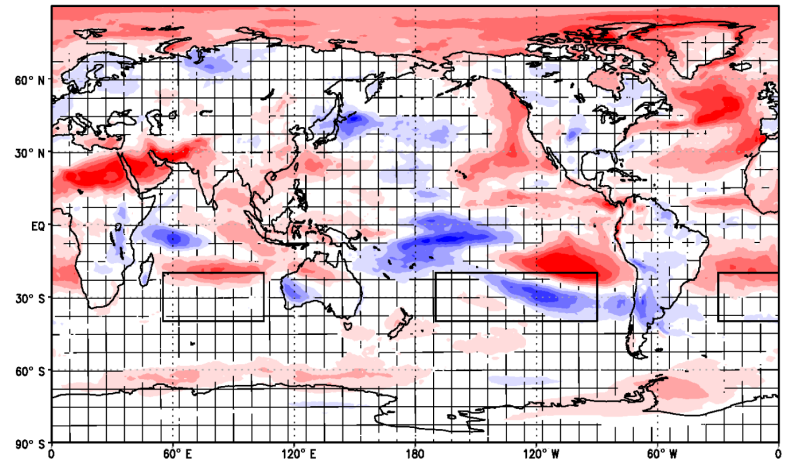

(b) Total cloud frac.: G4Foam-RCP6.0

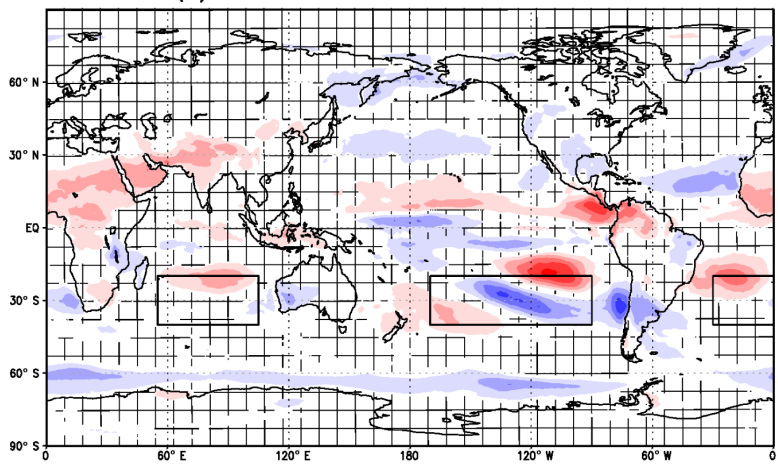

(d) JJA total cloud frac.: G4Foam-RCP6.0

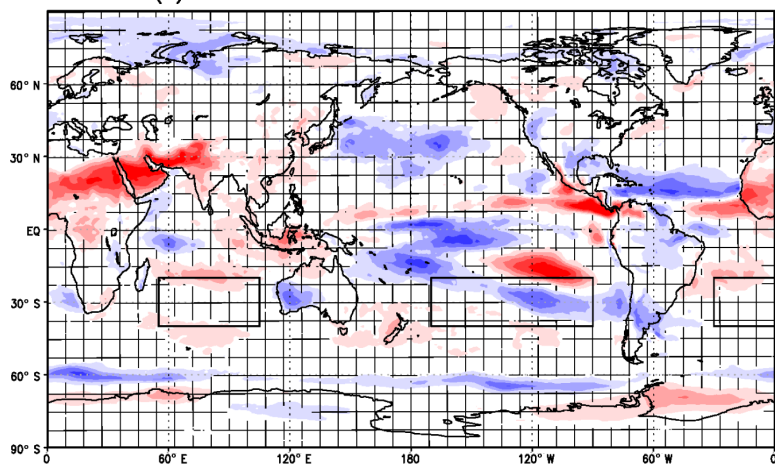

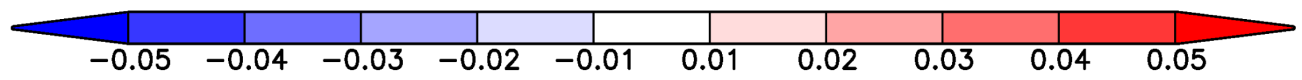

Figure 6. 2030-2069 total cloud fraction difference (unitless) between G4Foam and (a) G4SSA, (b) RCP6.0, (c) G4SSA during JJA, and (d) RCP6.0 during JJA. Hatched regions are areas with $p>0.05$ (where changes are not statistically significant based on a paired $t$ test). Black boxes enclose foamed regions.

enhanced low-cloud fraction response is similar to the seasonal cycle of marine low clouds around the periphery of the subtropical highs (Wood and Bretherton, 2004; Chiang and Bitz, 2005; Wood and Bretherton, 2006; George and Wood, 2010; Mechoso et al., 2014).

The relationship between the strength of the subtropical high, inversion strength, and marine cloud prevalence can be elucidated by analogy to the behavior of the very wellobserved marine low clouds off of the California coast. The strength of the inversion and the prevalence of marine low clouds are modulated by the annual cycle with annual maximum low-cloud extent in the summer, when the subtropical high is at its strongest. The increased low-cloud fraction response is not seen above the actual G4Foam-forced regions despite the cooler SST. The subsidence is so strong in these areas that the base of the inversion falls below the lifting condensation level, and few clouds form (Fig. 5).

Another striking G4Foam feature is the large and statistically significant increase in low clouds over land across central Africa, the Middle East, and Southeast Asia. These low clouds are coincident with the large cooling in Africa and the
Middle East, particularly during the JJA season relative to both G4SSA and RCP6.0 (Fig. 5c, d). These are very hot areas and heat-related mortality and morbidity are of great concern. A similar increase in low clouds is evident in the tropical eastern Pacific. This is coincident with the mean northward displacement of the ITCZ in G4Foam with respect to G4SSA and RCP6.0, not with any changes in the El NiñoSouthern Oscillation (ENSO).

In G4Foam, clouds are the key to changing the radiation budget in the tropics. In G4Foam there is a change in shortwave cloud forcing of -2.32 annually and $-2.59 \mathrm{~W} \mathrm{~m}^{-2}$ during JJA, relative to G4SSA. Only very small increases in long-wave cloud forcing of 0.42 annually and $0.07 \mathrm{~W} \mathrm{~m}^{-2}$ in JJA counter this negative forcing. The overall change in cloud radiative forcing in the tropics is -1.90 annually and $-2.52 \mathrm{~W} \mathrm{~m}^{-2}$ during JJA. Relative to RCP6.0, in G4Foam there is a change in shortwave cloud forcing of -0.68 annually and $-0.89 \mathrm{~W} \mathrm{~m}^{-2}$ during JJA, relative to RCP6.0. Small increases in long-wave cloud forcing of 0.40 annually, and $0.28 \mathrm{~W} \mathrm{~m}^{-2}$ in JJA counter part of this negative forcing. The overall change in cloud radiative forcing in G4Foam in the 
(a) Precip.: G4Foam-G4SSA (\%)

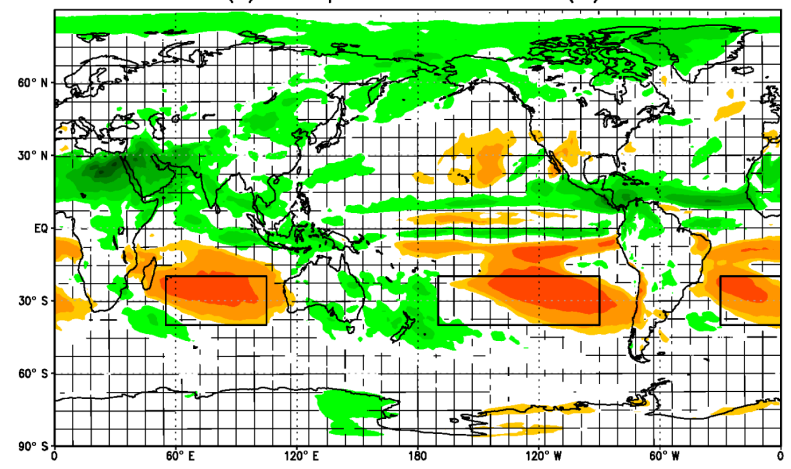

(c) JJA precip.: G4Foam-G4SSA (\%)

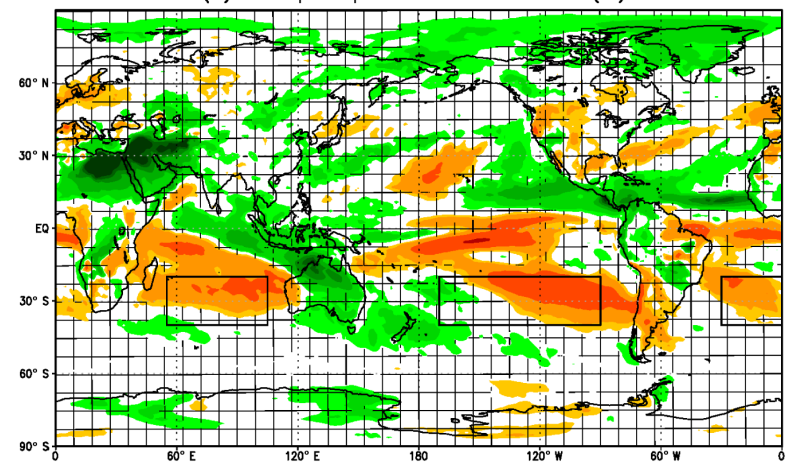

(b) Precip.: G4Foam-RCP6.0 (\%)

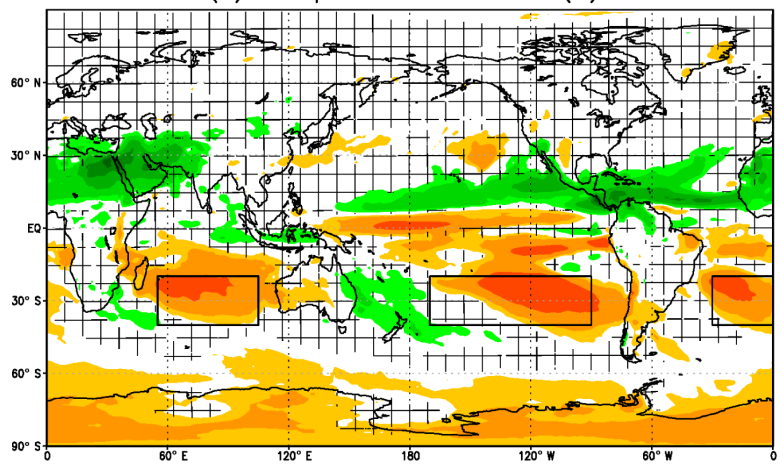

(d) JJA precip.: G4Foam-RCP6.0 (\%)

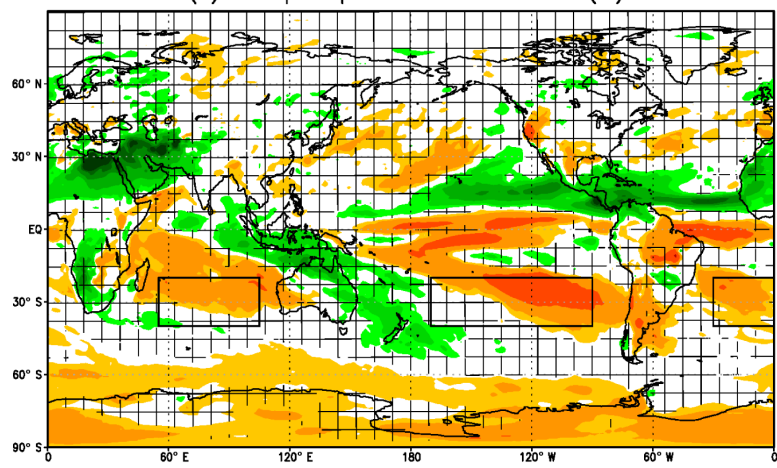

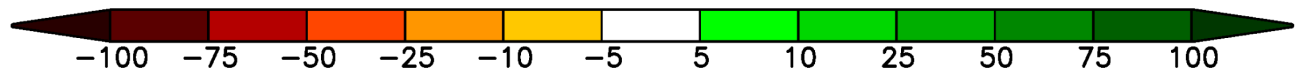

Figure 7. 2030-2069 precipitation difference (\%) between G4Foam and (a) G4SSA, (b) RCP6.0, (c) G4SSA during JJA, and (d) RCP6.0 during JJA. Hatched regions are areas with $p>0.05$ (where changes are not statistically significant based on a paired $t$ test). Black boxes enclose foamed regions.

tropics is -0.49 annually and $-0.61 \mathrm{~W} \mathrm{~m}^{-2}$ during JJA when compared to RCP6.0

Total cloud fraction is shown in Fig. 6. Figure $6 \mathrm{c}$ and $\mathrm{d}$ are particularly striking in showing the increase in clouds over Africa and Southeast Asia during the JJA wet monsoon season in those regions. Under G4Foam, these regions generally experience cloudier and cooler summers relative to RCP6.0 and are cloudier and only very slightly warmer on average compared to G4SSA. Some parts of the Sahel and the Middle East are actually slightly cooler in G4Foam than RCP6.0. These changes in temperature and cloudiness play a key role in the changes in the hydrological cycle under G4Foam, which we discuss next.

\subsection{Hydrological cycle response}

Relative to G4SSA, precipitation in G4Foam over land in the tropics increases by $3.2 \%$ on an annual mean basis and by $3.9 \%$ during JJA (Table 1). Tropical precipitation in G4Foam over land in the tropics increases by $1.4 \%$ on an annual mean basis and by $2.02 \%$ during JJA, when compared to RCP6.0. Each of these changes is statistically signif- icant $(p<0.05)$. Regarding the temperature change relative to G4SSA, G4Foam is only about $0.3 \mathrm{~K}$ warmer in the tropics. Precipitation is expected to increase by between 1.5 and $3.0 \% \mathrm{~K}^{-1}$ as global mean temperature increases (Emori and Brown, 2005). The temperature difference between G4Foam and G4SSA can explain only a fraction of the precipitation increase. The statistically significant increase in land-only precipitation in the tropics in G4Foam relative to RCP6.0 occurs in a climate in which RCP6.0 is between 0.6 and $0.7 \mathrm{~K}$ warmer than G4Foam, depending on the season. Over the tropical oceans, in G4Foam, precipitation is reduced by $0.4 \%$ on an annual mean basis and reduced by $0.3 \%$ during JJA relative to G4SSA. There is a decrease of $2.6 \%$ on an annual mean basis and a decrease of $2.5 \%$ during JJA relative to RCP6.0.

Globally, over land, the precipitation response is similar to that in the tropics during JJA, but the magnitude of precipitation change is a bit less. Precipitation is statistically significantly increased over land in G4Foam relative to RCP6.0 by about $0.5 \%$, despite G4Foam being cooler than RCP6.0. Precipitation is statistically significantly increased in G4Foam 
relative to G4SSA over land by $3.5 \%$, despite G4Foam only being $0.3 \mathrm{~K}$ warmer than G4SSA.

The overall global precipitation difference between G4Foam and G4SSA or RCP6.0, when land and ocean are combined and all seasons and all latitudes are included, is relatively small, and close to the 1.5 to $3 \% \mathrm{~K}^{-1}$ range of precipitation increase with temperature identified by Emori and Brown (2005). Globally, G4Foam is warmer than G4SSA by $0.3 \mathrm{~K}$ and there is $0.61 \%\left(2.1 \% \mathrm{~K}^{-1}\right)$ more precipitation. G4Foam is cooler than RCP6.0 by $0.6 \mathrm{~K}$ and drier by $1.9 \%$ $\left(3.1 \% \mathrm{~K}^{-1}\right)$.

The spatial pattern of precipitation changes is shown in Fig. 7. Precipitation is greatly reduced over the ocean, particularly in the SH, relative to both G4SSA and RCP6.0. Changes in precipitation poleward of $40^{\circ}$ latitude in either hemisphere are largely due to the temperature dependence of precipitation. The changes in the SH subtropics are dominated by the shortwave forcing applied over the ocean gyres, which reduces both evaporation and precipitation in those areas.

The changes in precipitation in the tropics are driven by a northward shift in the ITCZ. Large precipitation anomalies occur in a narrow band north of the equator and smaller positive anomalies occur in broader regions, primarily over $\mathrm{NH}$ monsoon regions. Importantly, we see a statistically significant increase in monsoon precipitation over the Sahel, the Middle East, and the Indian subcontinent as well as southwest Asia and the Maritime Continent on an annual mean basis in G4Foam relative to G4SSA (Fig. 7a). Relative to RCP6.0, these changes are not statistically significant over the Indian subcontinent or southwest Asia, but there are only very isolated and small areas in these regions in which there is any precipitation reduction, either on the annual mean or during JJA. Therefore, over much of heavily populated southern Asia, east of the Arabian Sea, G4Foam will be cooler than RCP6.0 without any notable mean precipitation differences. Most of these areas are expected to receive more rainfall as the planet warms. If this excess rainfall is not desirable in areas that are already wet, these results suggest that weakening the hydrological cycle would require that G4Foam would have to be combined with an additional geoengineering technique, such as stratospheric SRM.

Relative to both G4SSA and RCP6.0, there is a great deal more precipitation all year and particularly during JJA over Central America, the northern Amazon, much of Africa, parts of the Arabian peninsula, and the Maritime Continent. This response is more robust than the response over Southeast Asia due to the more direct dependence of rainfall in these regions on ITCZ position than in Southeast Asia, where the monsoon is also driven by numerous local and remote factors, including ENSO and the Indian Ocean dipole (IOD).

Although these G4Foam simulations enhance rainfall over many heavily populated and highly cultivated regions, particularly in the tropics, there are regions that would receive less precipitation and experience a decrease in $P-E$ (precipita- tion - evaporation) under this regime. Precipitation patterns for islands in the South Pacific are largely governed by the position and strength of the South Pacific Convergence Zone (SPCZ), which changes substantially under G4Foam due in part to the cooling and to the movement of gradients of temperature and pressure. Precipitation deficits over Madagascar and some regions in Africa and South America exceed $10 \%$.

While the changes in precipitation are important and useful in describing the climate response in G4Foam, the change in precipitation minus evaporation between G4Foam and G4SSA or RCP6.0 is more relevant to total available moisture. Figure 8 shows precipitation minus evaporation. Specifically, Fig. 8a shows that precipitation minus evaporation in G4Foam is increased, and this increase is significant relative to G4SSA across the Sahel, all of southern Asia, the Maritime Continent, Central America, and the northern Amazon. These are all heavily populated regions that are heavily cultivated. Figure $8 \mathrm{~b}$ shows a similar pattern, albeit with the regions with significantly higher $P-E$ is slightly suppressed in coverage, when G4Foam is compared to the warmer RCP6.0 rather than G4SSA. Figure $8 \mathrm{c}$ and d show changes in $P-E$ during JJA, the NH wet monsoon season, when water is likely needed the most. Due to variability in the monsoon, there is more heterogeneity in the JJA response than the annual response, particularly across Southeast Asia. The $P-E$ gain, driven by a combination of increased precipitation, lower temperature, and increased cloudiness in these heavily cultivated regions, could be an important benefit of G4Foam. However, G4Foam increased precipitation to levels that exceed that simulated in RCP6.0.

Figure 9 shows the differences of annual cycles from 2030 to 2069 for zonal mean precipitation, zonal mean precipitation minus evaporation, and zonal mean precipitable water between G4Foam and G4SSA and between G4Foam and RCP6.0. They illustrate the northward displacement of the ITCZ, with positive precipitation anomalies progressing poleward as the boreal summer monsoon progresses. Figure 9f shows the difference in the zonal mean annual cycle for column-integrated precipitable water between G4Foam and RCP6.0. The striking feature here is that zonal mean precipitation is higher at key latitudes in the tropics, despite zonal mean column-integrated precipitable water being much lower at the same latitude.

In Fig. 10, we quantify the impacts on agriculture by looking at the photosynthesis rate anomalies between G4Foam and RCP6.0. There are small but statistically significant increases in the photosynthesis rate in G4Foam relative to RCP6.0 in much of Southeast Asia. The most dramatic changes occur in Central America and parts of the northern Amazon, where the high $\mathrm{CO}_{2}$, relatively cool, and very wet conditions promote agriculture. 
(a) Precip.-evap.: G4Foam-G4SSA (mm day $\left.{ }^{-1}\right)$

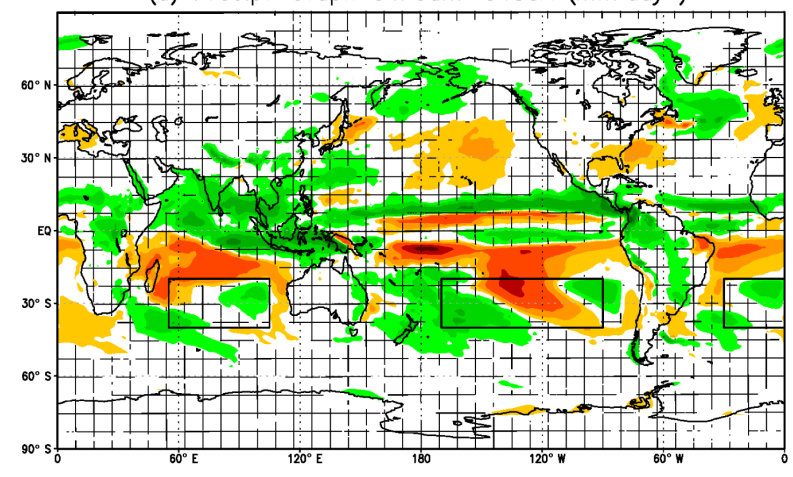

(c) JJA precip.-evap.: G4Foam-G4SSA (mm day-1)

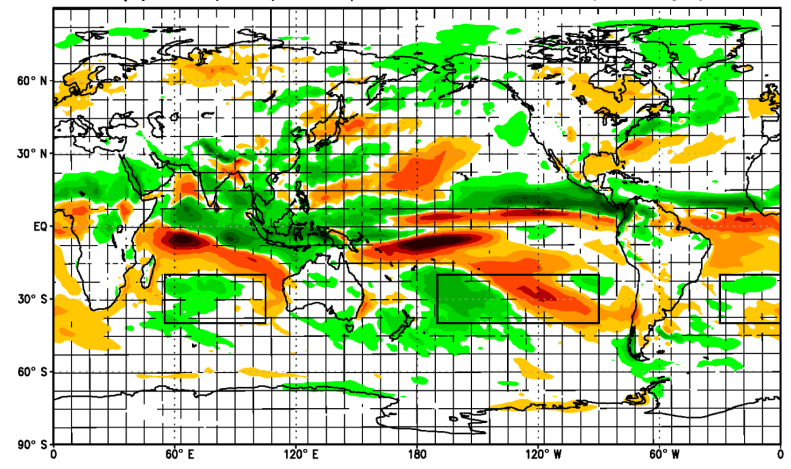

(b) Precip.-evap.: G4Foam-RCP6.0 (mm day $\left.{ }^{-1}\right)$

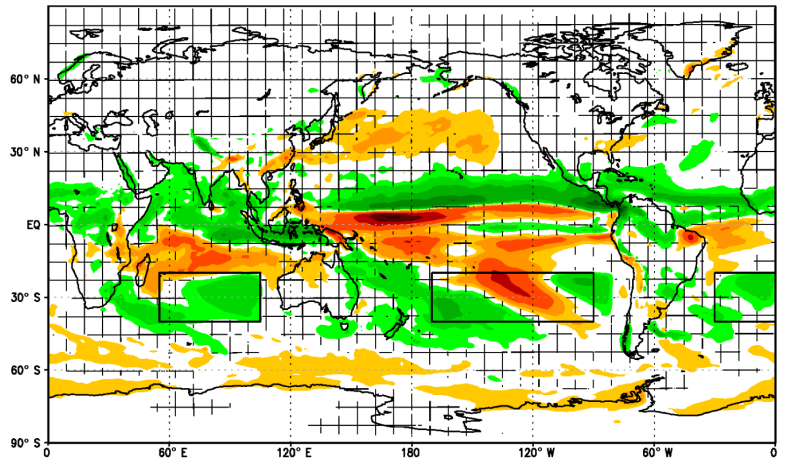

(d) JJA precip.-evap.: G4Foam-RCP6.0 (mm day-1)

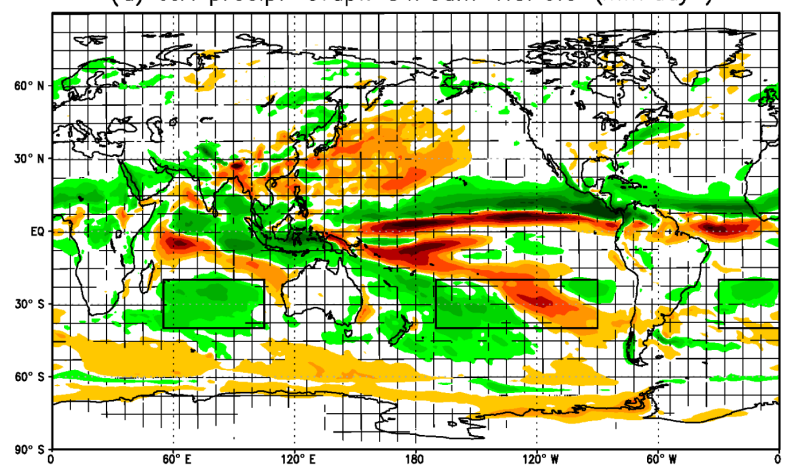

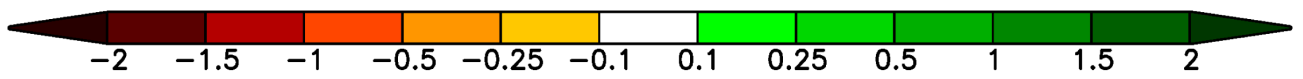

Figure 8. 2030-2069 precipitation minus evaporation difference (mm day ${ }^{-1}$ ) between G4Foam and (a) G4SSA, (b) RCP6.0, (c) G4SSA during JJA, and (d) RCP6.0 during JJA. Hatched regions are areas with $p>0.05$ (where changes are not statistically significant based on a paired $t$ test). Black boxes enclose foamed regions.

\section{Discussion}

This paper is an analysis of a geoengineering climate model experiment. Although for this experiment, global warming is reduced without seriously affecting precipitation, as was found in previous stratospheric aerosol implementations, this does not argue for the implementation of climate engineering. Any such decisions will need to balance all the risks and benefits of such implementation, and compare them to those from other possible responses to global warming.

\subsection{Summary}

G4Foam would reduce global mean surface temperature relative to RCP6.0 by $0.6 \mathrm{~K}$ for the 40 -year period starting 10 years after the implementation of geoengineering. Clearsky top-of-atmosphere net shortwave flux is reduced by $1.5 \mathrm{~W} \mathrm{~m}^{-2}$ in G4Foam relative to RCP6.0. This is achieved primarily by the shortwave forcing over the subtropical SH ocean gyres. Before accounting for feedbacks, temperature is more sensitive to the forcing applied in G4Foam than G4SSA. However, global mean surface temperature in G4SSA is $0.3 \mathrm{~K}$ lower than G4Foam because of a larger change in all-sky top-of-atmosphere net shortwave flux (Fig. 3). Additionally, the latitudinal distribution of temperature reduction is different in G4Foam than in G4SSA. G4SSA is most effective in cooling the NH continents, while G4Foam most effectively cools the surface south of around $30^{\circ} \mathrm{N}$ (Fig. 4).

Precipitation over land globally, in the tropics, during JJA globally, and during JJA in the tropics is statistically significantly increased in G4Foam relative to both G4SSA and RCP6.0 (Fig. 7). The increase in precipitation in G4Foam relative to RCP6.0 is very likely undesirable in areas that already receive a lot of rainfall. The combination of cooling and increased precipitation over land in the tropics results in a statistically significant increase in precipitation minus evaporation on an annual mean basis over Central America, the Northern Amazon, the Sahel, the Indian subcontinent, the Maritime Continent and Southeast Asia in G4Foam relative to G4SSA (Fig. 8). All of these areas are very densely populated and heavily cultivated. Water scarcity is a major is- 

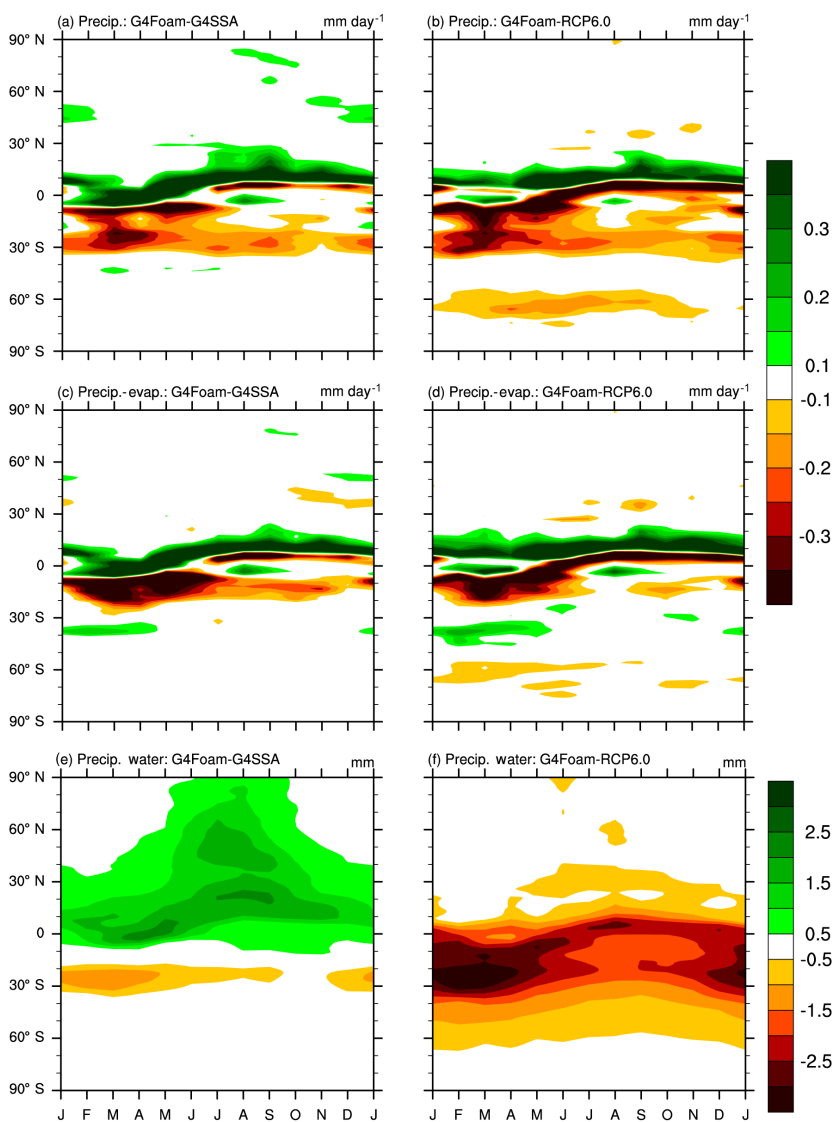

Figure 9. 2030-2069 monthly mean annual cycle of zonal mean precipitation $\left(\mathrm{mm} \mathrm{day}^{-1}\right.$ ) for (a) G4Foam minus G4SSA and (b) G4Foam minus RCP6.0, precipitation minus evaporation $\left(\right.$ mm day $^{-1}$ ) for (c) G4Foam minus G4SSA and (d) G4Foam minus RCP6.0, and total precipitable water (mm) for (e) G4Foam minus G4SSA and (f) G4Foam minus RCP6.0.

sue in many of these areas and G4Foam describes a climate model response in which there is global cooling, but higher $P-E$ is modeled for many regions, some of which are in need of greater water supply. However, in order to assess actual changes in water supply, it would be necessary to analyze extreme events, as well as the economic and policy issues that ultimately determine the allocation of water resources in a given region.

Finally, both the changes in the spatial pattern and magnitude of changes in temperature and precipitation are far too large to be explained by the forcing alone. Instead, much of the temperature and hydrological response is the result of powerful cloud feedbacks and changes in the tropical meridional overturning circulation induced by the placement of the ocean albedo forcing.

\subsection{The hydrological response}

The dominant cause of the G4Foam hydrological response is the intensification of the southern Hadley cell and the north-

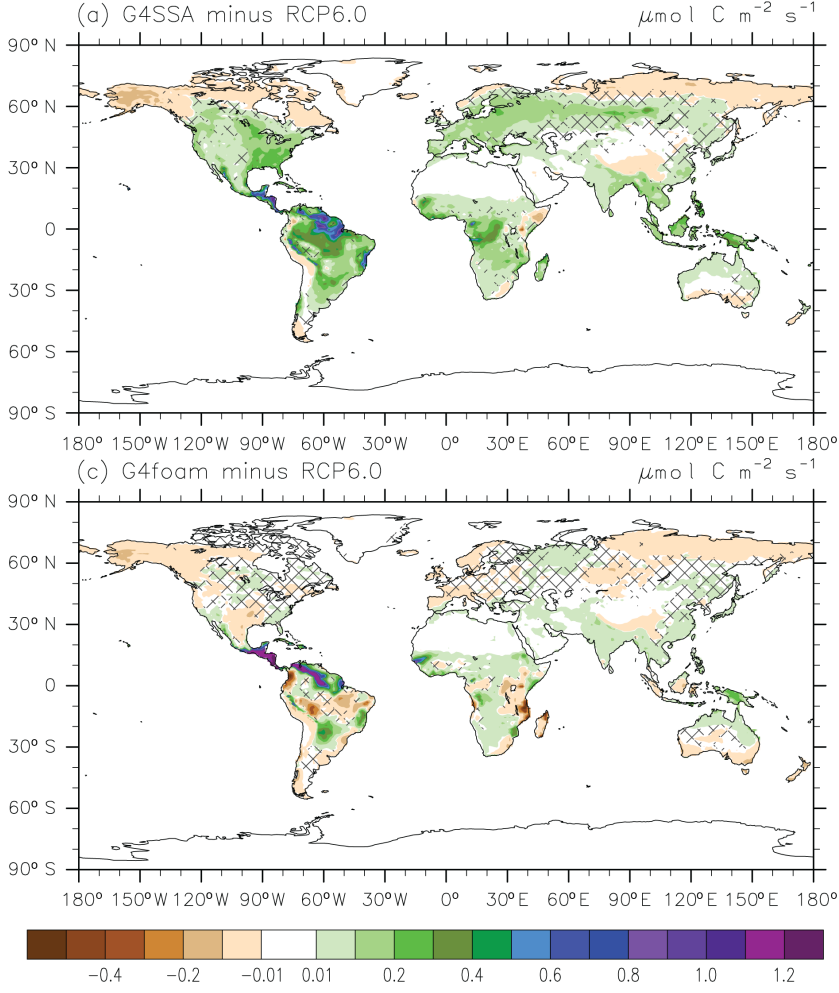

Figure 10. (a) Photosynthesis rate differences between G4SSA and RCP6.0 during years 2030-2069 (sulfate injection period, excluding the first 10 years; Fig. 4 a from Xia et al., 2016). (b) Photosynthesis rate anomaly between G4Foam and RCP6.0 during years 20302069 of solar reduction. Hatched regions are areas with $p>0.05$ (where changes are not statistically significant based on a paired $t$ test).

ward migration of the ITCZ in response to the asymmetric forcing. However, the precipitation response is not zonally homogeneous, as the regional and local mechanisms are also important to the distribution of precipitation.

First, we address the increase in precipitation over Central America. For this, we turn to literature concerning the decline of Mayan civilization in Central America. Summer insolation in the NH began to decrease about 5000 years ago. The ITCZ migrated southward. This southward shift caused rainfall to decrease in the crucial summer growing season. Long droughts and eventually water shortages contributed to the civilization's decline (Poore et al., 2004). In G4Foam, the ITCZ moves northward and the areas in which Mayan civilization flourished, including Belize, Guatemala and parts of Mexico, once again receive a great deal more precipitation. This response is strong and consistent in each ensemble member (Figs. 6-8).

The long mid-to-late 20th century Sahel drought was primarily caused by the ITCZ being pushed southward by preferential cooling of the NH (Folland, 1986). In G4Foam, the reverse is true. SH cooling pushes the ITCZ north, which 
generally explains the G4Foam precipitation increase in the Sahel.

A surprising finding is that portions of the Arabian Peninsula equatorward of $20^{\circ} \mathrm{S}$ experience precipitation increases of up to $1 \mathrm{~mm} \mathrm{day}^{-1}$ during the JJA season. However, this northward migration of boreal summer precipitation is evident in the paleoclimate record. Evidence of such precipitation is found in Fleitmann et al. (2003), who showed changes in $\delta^{18} \mathrm{O}$ in cave stalagmites in Oman, which indicate increased rainfall in Oman under the influence of northward movement of the ITCZ over the Indian Ocean in periods of relative warmth in the $\mathrm{NH}$ relative to the $\mathrm{SH}$.

Changes in precipitation over the Maritime Continent are partially attributable to large-scale convergence and rising air in those regions, as they lie longitudinally between G4Foam forcing zones where subsidence is enhanced. However, the Indian Ocean dipole (Cai et al., 2012; Chowadry et al., 2012) and subtropical Indian Ocean dipole (SIOD) phenomena discussed below are more likely to be the key drivers of the precipitation response over the Maritime Continent.

In its positive phase, the SIOD features anomalously warm SSTs in the southwestern Indian Ocean, east and southeast of Madagascar, and cold anomalies of SST west of Australia. Stronger winds prevail along the eastern edge of the SH subtropical high over the Indian Ocean, which becomes intensified and shifted slightly to the south during positive SIOD events. This results in more evaporation over the eastern Indian Ocean, which cools SSTs in the Indian Ocean east of Australia (Suzuki et al., 2004). In the SIOD negative phase, the opposite is true. There is cooler water in the southwest Indian Ocean, near Madagascar, and warmer waters to the east, near Australia (Behera et al., 2001; Reason, 2001).

The negative phase of the SIOD features more precipitation in western Australia and the Maritime Continent. This negative SIOD phase is consistent with the SST pattern in the Indian Ocean forced by G4Foam. Therefore, the negative SIOD-like mean state in G4Foam appears to play a role in the enhanced rainfall in northwestern Australia and the Maritime Continent.

Based on both local and global changes in circulation, we expected a very large increase in the strength of the Indian monsoon. In addition to the planetary-scale changes associated with the ITCZ and the Hadley cell, the position of the semi-permanent high in the subtropical southern Indian Ocean also plays a large role in modulating the Indian summer monsoon. Negative SIOD events during boreal winter are often followed by strong Indian summer monsoons. During a negative SIOD event, the subtropical high in the Indian Ocean shifts northeastward as the season shifts from December, January, and February to JJA. This causes a strengthening of the monsoon circulation, intensifying the Hadley cell locally during the JJA monsoon.

A negative IOD is associated with a weakened Asian monsoon and an increase in precipitation over Australia and the Maritime Continent. In G4Foam, advection of cold water in the Somali current into the equatorial western Indian Ocean creates a negative IOD-like response that partially counters the combination of the global-scale Hadley cell response and the forced SIOD, dampening the overall increase in the Indian monsoon. This warm west-cold east mean state in the equatorial Indian Ocean resembles a negative IOD mean state and it helps to explain the enhanced precipitation response in the Maritime Continent and the lower than expected increase in precipitation over the Indian subcontinent. The Asian monsoon and precipitation over the Maritime Continent are also governed in part by ENSO. However, no changes in ENSO were evident in G4Foam relative to G4SSA or RCP6.0. There is also no evident response of ENSO amplitude or frequency to any of several different regimes of stratospheric geoengineering (Gabriel and Robock, 2015).

\subsection{Caveats}

The technology does not presently exist to actually deploy a stable, highly reflective layer of microbubbles on the ocean surface. While a stable, highly reflective, nondispersive foam has been developed in a saltwater solution, appropriate for climate engineering, this foam has not been tested outside the laboratory, much less on the surface of a large area of rarely quiescent ocean. The foam has not been immersed in a medium in which bacteria are present, and the interaction between the bacteria and the protein surfactant could damage the layer of microbubbles. Also, even though the diameter of these microbubbles is on the order of $10^{-6} \mathrm{~m}$, the demand for surfactant would likely overwhelm our current production capacity of whatever surfactant is chosen. The research on the engineering required to perform stratospheric geoengineering by sulfate injection is much further along than research of microbubble deployment, which is still in its earliest stages.

However, since development of microbubble technology is underway, it is worthwhile to determine how such a technology could be applied in a manner that would address serious climate issues. The progress being made in research associated with stratospheric geoengineering actually enhances the relevance of researching the climate impact of this particular ocean surface geoengineering approach, as G4Foam was designed with an eye toward concurrent deployment with stratospheric geoengineering in the event that the stratospheric geoengineering were to cause the precipitation deficits that many model studies have shown that it might.

More fundamentally, the propriety of any attempt to impose a the G4Foam forcing in an attempt to achieve the modeled G4Foam climate is premised on a value judgment that it is desirable to develop a technology that could redistribute essential resources between nations, in an attempt to achieve a net benefit to humanity as a collective when it knowingly creates a local scarcity of these essential re- 
sources. To some extent, making this value judgment is germane and is a prerequisite to the discussion of any form of geoengineering. Even though G4Foam would be successful in increasing $P-E$ in more heavily populated areas, $P-E$ will almost certainly be reduced in remote regions, such as South Pacific islands. Is it ethical to pick winners and losers when the selection process is aimed at increasing the number of winners and decreasing the number of losers? Hypothetically, if G4Foam worked as described in this paper, from a purely consequentialist perspective, and with the sole objective being increased utility for the human collective, G4Foam could be considered beneficial.

Finally, this paper is concerned with the climate response to surface albedo changes. We do not examine how placing an actual layer of microbubbles in the ocean would change ocean circulation or impact chemistry and biology in the ocean. Evaluating the changes in the ocean, especially changes in its circulation that are caused by the surface albedo modification, is one of the next issues to explore. The ocean regions we propose to brighten have low biological productivity and weak currents, but the possibility of remote impacts, due to changes in circulation having negative impacts on important ocean regions, is worth considering.

\subsection{Future research}

Whether or not a concurrent deployment of stratospheric geoengineering and ocean albedo modification could cool the entire planet while maintaining or enhancing the hydrological cycle, particularly in the tropics, is the next natural step in this research. Such research is motivated by the need to determine whether some combination of geoengineering techniques can be used to offset regional climate disparities that using one method of geoengineering alone could induce.

\section{Data availability}

Descriptions of data and links to output of this and other GeoMIP experiments, can be found at the GeoMIP homepage http://climate.envsci.rutgers.edu/GeoMIP/ data.html. Additional data from this experiment can be found at http://climateresearch.envsci.rutgers.edu/corey. The underlying research data can be accessed by contacting the corresponding author at cjgabriel7@gmail.com.

Acknowledgements. We thank two anonymous referees for their valuable comments, which improved this paper. This work is supported by US National Science Foundation (NSF) grants AGS-1157525, GEO-1240507, and AGS-1617844. Computer simulations were conducted on the National Center for Atmospheric Research (NCAR) Yellowstone supercomputer. NCAR is funded by NSF. The CESM project is supported by NSF and the Office of Science (BER) of the US Department of Energy. The Pacific Northwest National Laboratory is operated for the US Department of Energy by Battelle Memorial Institute under contract DE-AC05-76RL01830.

Edited by: L. M. Russell

Reviewed by: two anonymous referees

\section{References}

Aswathy, V. N., Boucher, O., Quaas, M., Niemeier, U., Muri, H., Mülmenstädt, J., and Quaas, J.: Climate extremes in multi-model simulations of stratospheric aerosol and marine cloud brightening climate engineering, Atmos. Chem. Phys., 15, 9593-9610, doi:10.5194/acp-15-9593-2015, 2015.

Aziz, A., Hailes, H. C., Ward, J. M., and Evans, J. R. G.: Longterm stabilization reflective foams in seawater, Roy. Soc. Ch., 95, 53028-53036, 2014.

Behera, S. K. and Yamagata, T.: Subtropical SST dipole events in the southern Indian Ocean, Geophys. Res. Lett., 28, 327-330, 2001.

Bonan, G. B., Lawrence, P. J., Oleson, K. W., Levis, S., Jung, M., Reichstein, M., Lawrence, D. M., and Swenson, S. C.: Improving canopy processes in the Community Land Model version 4 (CLM4) using global flux fields empirically inferred from FLUXNET data, J. Geophys. Res., 116, G02014, doi:10.1029/2010JG001593, 2011.

Broccoli, A. J., Dahl, K. A., and Stouffer, R. J.: The response of the ITCZ to Northern Hemisphere cooling, Geophys. Res. Lett., 33, L01702, doi:10.1029/2005GL024546, 2006.

Cai W., Van Rensch P., Cowan T., and Hendon H. H.: Teleconnection pathways for ENSO and the IOD and the mechanism for impacts on Australian rainfall, J. Climate, 24, 3910-3923, doi:10.1175/2011JCLI4129.1, 2011.

Chao, W. C. and Chen, B.: The origin of the monsoons, J. Atmos. Sci., 58, 3497-3507. 2001.

Chiang, J. C. H. and Bitz, C. M.: Influence of high latitude ice cover on the marine Intertropical Convergence Zone, Clim. Dynam. 25, 477-496, 2005.

Chowdary, J. S., Xie, S.-P., Tokinaga, H., Okumura, Y. M., Kubota, H., Johnson, N., and Zheng, X.-T.: Interdecadal variations in ENSO teleconnection to the Indo-western Pacific for 1870-2007, J. Climate, 25, 1722-1744, doi:10.1175/JCLI-D-11$00070.1,2012$

Crutzen, P.: Albedo enhancement by stratospheric sulfur injections: A contribution to solve a policy dilemma?, Climatic Change, 77, 211-219, 2006.

Cvijanovic, I., Caldeira, K., and MacMartin, D.G.: Impacts of ocean albedo alteration on Arctic sea ice restoration and Northern Hemisphere climate, Environ. Res. Lett., 10, 044020, doi:10.1088/1748-9326/10/4/044020, 2015.

DeSzoeke, S. P., Verlinden, K. L., Yuter, S. E., and Mechem, D. B.: The Time Scales of Variability of Marine Low Clouds, J. Climate, 29, 6463-6481, doi:10.1175/JCLI-D-15-0460.1, 2016.

Dykema J. A., Keith D. W., Anderson J. G., and Weisenstein, D.: Stratospheric controlled perturbation experiment: a smallscale experiment to improve understanding of the risks of solar geoengineering, Philos. T. R. Soc. A, 372, 20140059, doi:10.1098/rsta.2014.0059, 2014. 
Emori, S. and Brown, S. J.: Dynamic and thermodynamic changes in mean and extreme precipitation under changed climate, Geophys. Res. Lett., 32, L17706, doi:10.1029/2005GL023272, 2005.

Fleitmann, D., Burns, S. J., Mudelsee, M., Neff, U., Kramers, J., Mangini, A., and Matter, A.: Holocene forcing of the Indian monsoon recorded in a stalagmite from Southern Oman, Science, 300, 1737-1739, 2003.

Folland, C. K., Parker, D. E., and Palmer, T. N.: Sahel rainfall and worldwide sea temperatures 1901-85, Nature, 320, 602-607, 1986.

Frierson, D. M. W. and Hwang, Y.-T.: Extratropical influence on ITCZ shifts in slab ocean simulation of global warming, J. Climate, 25, 720-733, 2012.

Gabriel, C. J. and Robock, A.: Stratospheric geoengineering impacts on El Niño/Southern Oscillation, Atmos. Chem. Phys., 15, 11949-11966, doi:10.5194/acp-15-11949-2015, 2015.

George, R. C. and Wood, R.: Subseasonal variability of low cloud radiative properties over the southeast Pacific Ocean, Atmos. Chem. Phys., 10, 4047-4063, doi:10.5194/acp-10-4047-2010, 2010.

Haywood, J. M., Jones, A., Bellouin, N., and Stephenson, D.: Asymmetric forcing from stratospheric aerosols impacts Sahelian rainfall, Nature Climate Change, 3, 660-665, doi:10.1038/nclimate1857, 2013.

Held, I. M. and Soden, B. J.: Robust responses of the hydrological cycle to global warming, J. Climate, 19, 5686-5699, 2006.

Hurley, J. V. and Boos, W. R.: Interannual variability of monsoon precipitation and local subcloud equivalent potential temperature, J. Climate, 26, 9507-9527, 2013.

Hwang, Y.-T., Frierson, D. M. W., and Kang, S. M.: Anthropogenic sulfate aerosol and the southward shift of tropical precipitation in the late 20th century, Geophys. Res. Lett., 40, 2845-2850, doi:10.1002/grl.50502, 2013.

IPCC: Summary for Policymakers, in: Climate Change 2013: The Physical Science Basis, Contribution of Working Group I to the Fifth Assessment Report of the Intergovernmental Panel on Climate Change, edited by: Stocker, T. F., Qin, D., Plattner, G.-K., Tignor, M., Allen, S. K., Boschung, J., Nauels, A., Xia, Y., Bex, V., and Midgley, P. M., Cambridge University Press, Cambridge, UK and New York, NY, USA, 2013.

Irvine, P. J., Ridgwell, A., and Lunt, D. J.: Climatic effects of surface albedo geoengineering, J. Geophys. Res., 116, D24112, doi:10.1029/2011JD016281, 2011.

Jones, A., Haywood, J., and Boucher, O.: Climate impacts of geoengineering marine stratocumulus clouds, J. Geophys. Res., 114, D10106, doi:10.1029/2008JD011450, 2009.

Kang, S. M., Held, I. M., Frierson, D. M. W., and Zhao, M.: The response of the ITCZ to extratropical thermal forcing: Idealized slab-ocean experiments with a GCM, J. Climate, 21, 3521-3532, 2008.

Kay J. E., Wall C., Yettella V., Medeiros B., Hannay C., Caldwell P., and Bitz C.: Global climate impacts of fixing the Southern Ocean shortwave radiation bias in the community earth system model (CESM), J. Climate, 96, 1333-13349, doi:10.1175/JCLID-15-0358, 2016.

Keith, D. W., Duren, R., and MacMartin, D. G.: Field experiments on solar geoengineering: report of a workshop exploring a representative research portfolio, Philos. T. R. Soc. A, 372, 20140175 , 2014.
Kharin, V. V., Zwiers, F. W., Zhang, X., and Hegerl, G. C.: Changes in temperature and precipitation extremes in the IPCC ensemble of Global Coupled Model Simulations, J. Climate, 20, 1419 1444, doi:10.1175/JCLI4066.1, 2007.

Kravitz, B., Robock, A., Boucher, O., Schmidt, H., Taylor, K., Stenchikov, G., and Schulz, M.: The geoengineering model intercomparison project (GeoMIP), Atmos. Sci. Lett., 12, 162-167, doi:10.1002/asl.316., 2011.

Kravitz, B., Robock, A., Tilmes, S., Boucher, O., English, J. M., Irvine, P. J., Jones, A., Lawrence, M. G., MacCracken, M., Muri, H., Moore, J. C., Niemeier, U., Phipps, S. J., Sillmann, J., Storelvmo, T., Wang, H., and Watanabe, S.: The Geoengineering Model Intercomparison Project Phase 6 (GeoMIP6): simulation design and preliminary results, Geosci. Model Dev., 8, 33793392, doi:10.5194/gmd-8-3379-2015, 2015.

Lamarque, J.-F., Emmons, L. K., Hess, P. G., Kinnison, D. E., Tilmes, S., Vitt, F., Heald, C. L., Holland, E. A., Lauritzen, P. H., Neu, J., Orlando, J. J., Rasch, P. J., and Tyndall, G. K.: CAM-chem: description and evaluation of interactive atmospheric chemistry in the Community Earth System Model, Geosci. Model Dev., 5, 369-411, doi:10.5194/gmd-5-369-2012, 2012.

Latham, J., Bower, K., Choularton, T., Coe, H., Connoly, P., Cooper, G., Craft, T., Foster, J., Gadian, A., Galbraith, L., Iacovides, H., Johnston, D., Launder, B., Leslie, B., Meyer, J., Neukermans, A., Ormond, B., Parkes, B., Rasch, P., Rush, J., Salter, S., Stevenson, T., Wang, H., Wang, Q., and Wood, R.: Marine cloud brightening, Philos. T. R. Soc. A, 370, 4217-4262, doi:10.1098/rsta.2012.0086, 2012.

Lindzen, R. S. and Hou, A. Y.: Hadley circulations for zonally averaged heating centered off the equator, J. Atmos. Sci., 45, 24162427, 1988.

Manabe, S. and Stouffer, R. J.: Sensitivity of a global climate model to an increase of $\mathrm{CO}_{2}$ concentration in the atmosphere, J. Geophys. Res., 85, 5529-5554, 1980.

Marcott, S. A., Shakun, J. D., Clark, P. U., and Mix, A. C.: A reconstruction of regional and global temperature for the past 11300 years, Science, 339, 1198-1201, 2013.

Mechoso, C., Wood, R., Weller, R., Bretherton, C. S., Clarke, A., Coe, H., Fairall, C., Farrar, J. T., Feingold, G., and Garreaud, R.: Ocean-cloud-atmosphere-land interactions in the southeastern Pacific: The VOCALS Program, B. Am. Meteorol. Soc., 95, 357-375, 2014.

Meehl, G. A., Arblaster, J. M., Caron, J. M., Annamalai, H., Jochum, M., Chakraborty, A., and Murtugudde, R.: Monsoon regimes and processes in CCSM4. Part I: The Asian-Australian Monsoon, J. Climate, 25, 2583-2608, 2012.

Meinshausen, M., Smith, S. J., Calvin, K., Daniel, J. S., Kainuma, M. L. T., Lamarque, J.-F., Matsumoto, K., Montzka, S. A., Raper, S. C. B., Riahi, K., Thomason, A., Velders, G. J. M., and van Vuuren, D. P. P.: The RCP greenhouse gas concentrations and their extension from 1765 to 2300 , Climatic Change, 109, 213 241, doi:10.1007/s10584-011-0156-z, 2011.

Mengis, N., Martin, T., Keller, D. P., and Oschlies, A.: Assessing climate impacts and risks of ocean albedo modification in the Arctic, J. Geophys. Res.-Oceans, 121, 3044-3057, doi:10.1002/2015JC011433, 2016.

Neale, R., Richter, J., Park, S., Lauritzen, P., Vavrus, S., Rasch, P., and Zhang, M.: The mean climate of the Community Atmo- 
sphere Model (CAM4) in forced SST and fully coupled experiments, J. Climate, 26, 5150-5168, 2013.

Neely III, R. R., Conley, A. J., Vitt, F., and Lamarque, J.-F.: A consistent prescription of stratospheric aerosol for both radiation and chemistry in the Community Earth System Model (CESM1), Geosci. Model Dev., 9, 2459-2470, doi:10.5194/gmd-9-24592016, 2016.

Poore, R. Z., Quinn, T. M., and Verardo, S.: Century-scale movement of the Atlantic Intertropical Convergence Zone linked to solar variability, Geophys. Res. Lett., 31, L12214, doi:10.1029/2004GL019940, 2004.

Rasch, P. J., Latham, J., and Chen, C. C.: Geoengineering by cloud seeding: influence on sea ice and climate system, Environ. Res. Lett., 4, 45-112, doi:10.1088/1748-9326/4/4/045112, 2009.

Reason, C. J. C.: Subtropical Indian Ocean SST dipole events and southern African rainfall, Geophys. Res. Lett., 28, 2225-2228, doi:10.1029/2000GL012735, 2001.

Robock, A.: 20 reasons why geoengineering may be a bad idea, B. Atom. Sci., 64, 14-18, doi:10.2968/064002006, 2008.

Robock, A.: Bubble, bubble, toil and trouble. An editorial comment, Climatic Change, 105, 383-385, doi:10.1007/s10584-010-0017$1,2011$.

Robock, A.: Stratospheric aerosol geoengineering, Environ. Sci. Technol., 38, 162-185, 2014.

Robock, A.: Albedo enhancement by stratospheric sulfur injection: More research needed, Earth's Future, 4, doi:10.1002/2016EF000407, 2016.

Seitz, R.: Bright water: hydrosols, water conservation and climate change, Climatic Change, 105, 365-381, 2010.

Siegenthaler, U., Stocker, T. F., Monnin, E., Luthi, D., Schwander J., Stauffer, B., Raynaud, D., Barnola, J. M., Fischer, H., Masson, Delmotte, V., and Jouzel, J.: Stable carbon cycle-climate relationship during the late Pleistocene, Science, 310, 1313-1317, 2005.

Suzuki, R., Behera, S. K., Iizuka, S., and Yamagata, T.: The Indian Ocean subtropical dipole simulated using a CGCM, J. Geophys. Res., 109, C09001, doi:10.1029/2003JC001974, 2004.

Taylor, K. E., Stouffer, R. J., and Meehl, G. A.: An overview of CMIP5 and the experiment design, B. Am. Meteorol. Soc., 93, 485-498, doi:10.1175/BAMS-D-11-00094.1, 2012.
Tilmes, S., Fasullo, J., Lamarque, J.-F., Marsh, D. R., Mills, M., Alterskjaer, K., Muri, H., Kristjánsson, J. E., Boucher, O., Schulz, M., Cole, J. N. S., Curry, C. L., Jones, A., Haywood, J., Irvine, P. J., Ji, D., Moore, J. C., Karam, D. B., Kravitz, B., Rasch, P. J., Singh, B., Yoon, J.-H., Niemeier, U., Schmidt, H., Robock, A., Yang, S., and Watanabe, S.: The hydrological impact of geoengineering in the Geoengineering Model Intercomparison Project (GeoMIP), J. Geophys. Res.-Atmos, 118, 11036-11058, doi:10.1002/jgrd.50868, 2013.

Tilmes, S., Mills, M. J., Niemeier, U., Schmidt, H., Robock, A., Kravitz, B., Lamarque, J.-F., Pitari, G., and English, J. M.: A new Geoengineering Model Intercomparison Project (GeoMIP) experiment designed for climate and chemistry models, Geosci. Model Dev., 8, 43-49, doi:10.5194/gmd-8-43-2015, 2015.

Tilmes, S., Lamarque, J.-F., Emmons, L. K., Kinnison, D. E., Marsh, D., Garcia, R. R., Smith, A. K., Neely, R. R., Conley, A., Vitt, F., Val Martin, M., Tanimoto, H., Simpson, I., Blake, D. R., and Blake, N.: Representation of the Community Earth System Model (CESM1) CAM4-chem within the ChemistryClimate Model Initiative (CCMI), Geosci. Model Dev., 9, $1853-$ 1890, doi:10.5194/gmd-9-1853-2016, 2016.

Trenberth, K. E., and Dai, A.: Effects of Mount Pinatubo volcanic eruption on the hydrological cycle as an ana$\log$ of geoengineering, Geophys. Res. Lett., 34, L15702, doi:10.1029/2007GL030524, 2007.

Wood, R. and Bretherton, C. S.: Boundary layer depth, entrainment, and decoupling in the cloud-capped subtropical and tropical marine boundary layer, J. Climate, 17, 3576-3588, 2004.

Wood, R. and Bretherton, C. S.: On the relationship between stratiform low cloud cover and lower-tropospheric stability, J. Climate, 19, 6425-6432, 2006.

Xia, L., Robock, A., Tilmes, S., and Neely III, R. R.: Stratospheric sulfate geoengineering could enhance the terrestrial photosynthesis rate, Atmos. Chem. Phys., 16, 1479-1489, doi:10.5194/acp16-1479-2016, 2016.

Xie, S.-P. and Philander, S. G. H.: A coupled ocean-atmosphere model of relevance to the ITCZ in the eastern Pacific, Tellus, 46A, 340-350, 1994. 